\title{
Targeted Intracellular Delivery of Antibodies: The State of the Art
}

\author{
Tatiana A. Slastnikova ${ }^{1 *}$, A. V. Ulasov' ${ }^{1}$ A. A. Rosenkranz ${ }^{1,2}$ and A. S. Sobolev ${ }^{1,2}$ \\ 1 Laboratory of Molecular Genetics of Intracellular Transport, Institute of Gene Biology, Russian Academy of Sciences, \\ Moscow, Russia, ${ }^{2}$ Faculty of Biology, M. V. Lomonosov Moscow State University, Moscow, Russia
}

\section{OPEN ACCESS}

Edited by:

Vsevolod V. Gurevich,

Vanderbilt University, United States

Reviewed by:

Chao Wang

University of North Carolina at Chapel Hill, United States Giovanna Montana,

Istituto di Biomedicina e di Immunologia Molecolare Alberto Monroy (IBIM), Italy

${ }^{*}$ Correspondence: Tatiana A. Slastnikova slacya@gmail.com

Specialty section:

This article was submitted to Experimental Pharmacology and Drug Discovery,

a section of the journal

Frontiers in Pharmacology

Received: 30 June 2018 Accepted: 03 October 2018 Published: 24 October 2018

Citation:

Slastnikova TA, Ulasov AV, Rosenkranz AA and Sobolev AS (2018) Targeted Intracellular Delivery of Antibodies: The State of the Art. Front. Pharmacol. 9:1208. doi: 10.3389/fphar.2018.01208
A dominant area of antibody research is the extension of the use of this mighty experimental and therapeutic tool for the specific detection of molecules for diagnostics, visualization, and activity blocking. Despite the ability to raise antibodies against different proteins, numerous applications of antibodies in basic research fields, clinical practice, and biotechnology are restricted to permeabilized cells or extracellular antigens, such as membrane or secreted proteins. With the exception of small groups of autoantibodies, natural antibodies to intracellular targets cannot be used within living cells. This excludes the scope of a major class of intracellular targets, including some infamous cancer-associated molecules. Some of these targets are still not druggable via small molecules because of large flat contact areas and the absence of deep hydrophobic pockets in which small molecules can insert and perturb their activity. Thus, the development of technologies for the targeted intracellular delivery of antibodies, their fragments, or antibody-like molecules is extremely important. Various strategies for intracellular targeting of antibodies via protein-transduction domains or their mimics, liposomes, polymer vesicles, and viral envelopes, are reviewed in this article. The pitfalls, challenges, and perspectives of these technologies are discussed.

Keywords: antibody intracellular delivery, subcellular drug delivery, protein delivery systems, cancer, intracellular transport

\section{INTRODUCTION}

First established in the 1950s, the drug delivery field has since grown substantially and evolved through several generations (Yun et al., 2015), from simple formulations for oral and transdermal delivery to complex delivery systems with the ability to overcome biological barriers. A simple search for "drug delivery" in PubMed reveals a slow growth in the number of results until the early 2000 s, followed by rapid expansion up to 2015, and a subsequent plateau of approximately 15,000 publications per year. Nevertheless, a tremendous number of in-demand drugs exert effects within cells, and an increasing number of new drugs intended to influence protein regulatory pathways (Higueruelo et al., 2013) are realized through protein-protein interactions (PPI). Pharmaceuticals acting on intracellular macromolecules must be delivered intracellularly into the target cells. Small molecules, which include most drugs, often cross biological membranes readily owing to

Abbreviations: CPP, cell penetrating peptide; DARPin, designed ankyrin repeat protein; ER, endoplasmic reticulum; Fab, antigen-binding fragment; GFP, green fluorescent protein; HCV, human hepatitis C virus; HIV, human immunodeficiency virus; HPV, human papilloma virus; IgG, immunoglobulin G; mAb, monoclonal antibody; NLS, nuclear localization signal; PCNA, proliferating cell nuclear antigen; PPI, protein-protein interactions; ScFv, single-chain variable fragments; TAT protein, HIV 1 trans-activating protein; VL, variable domain light chain. 
their size, amphiphilic nature, and the availability of transmembrane carriers. Meanwhile, despite the generally successful transmembrane penetration of many small molecules, some potential intracellular targets are excluded from their modulation. Among such elusive targets, are certain PPIs that regulate essential cellular functions and contribute to the signaling pathways involved in cancer pathogenesis (Lazo and Sharlow, 2016). Small molecules are often less effective than macromolecules for the interruption of PPIs, except for proteins with small-molecule-binding pockets such as enzymes, ion channels, and cell receptors (Crews, 2010), because of the large flat contact areas and lack of poorly defined deep pockets and grooves in which small molecules could insert and subsequently perturb its activity. PPIs often involve large surfaces, which typically range from 1500 to $3000 \AA^{2}$, compared with 300-1000 $\AA^{2}$ in protein interactions with small molecules (Wells and McClendon, 2007). A typical example of PPIs is the interaction of antibodies with protein antigens. In recent years, trends have revealed the growing impact of approved polypeptide macromolecular drugs, particular antibodies to cell-surface and soluble targets (de la Torre and Albericio, 2018; Strohl, 2018).

The size of the human interactome size was estimated to include 650,000 or more distinct interactions (Stumpf et al., 2008), but this estimation has since increased (Kotlyar et al., 2017). Recent analysis has revealed that only a small part of the human proteome (less than 700 proteins) is pharmaceutically accessible by approved drugs (Santos et al., 2017), which has led to the concept of "undruggable" targets that are not amenable to small-molecule interventions. This list includes certain infamous and notorious cancer-causing molecules, such as c-Myc, Ras, and NF-кB (Cox et al., 2014; Lazo and Sharlow, 2016; Dang et al., 2017). Intracellular proteins that act at immune checkpoints are other possible targets (Klepsch et al., 2018) for which inhibition by antibodies might reactivate the host's immune response against cancer cells. In this regard, a huge field of applications has been opened for intracellular treatment and diagnostics using antibodies. One mechanism of antibody action is the alteration of signal transduction through a physical block of the interaction between two proteins that are components of a cellular pathway (Adams and Weiner, 2005). This is exemplified by antibodies binding receptors, such as those of the EGFR family, on cell membranes, and sterically preventing them from transmitting a signal (Weiner et al., 2010). The tumor signaling perturbation through antibody interference has been shown to be a successful approach for the treatment of some diseases (Lenz, 2006; Hudis, 2007). The feasibility of antibodies to downregulate intracellular targets has been proven in experiments with microinjections (Riabowol et al., 1988; Gire and Wynford-Thomas, 1998; Ma et al., 1999) and transfections with a corresponding gene (intrabody approach Southwell et al., 2009; Ryan et al., 2010; Amici et al., 2016). However, the microinjection technique is limited to a small number of cells in vitro. The intrabody format has the potential for development, but still exhibits the same risks as gene therapy: the possible genome integration of viral vectors, low efficiency, and possible toxicity of non-viral vehicles, which has necessitated the development of direct antibody introduction methods. Currently, the routine introduction of antibodies into cells to visualize the cellular targets requires membrane permeabilization, which prevents the practical implementation of antibodies against intracellular targets for therapeutic purposes. Thus, the development of convenient technologies for the targeted delivery of antibodies, their fragments, or antibody-like molecules inside living cells without harming the cells is urgently needed. This overall task contains several stages, such as target-cell recognition, internalization, and transport to a relevant intracellular compartment. To date, the relevant literature details different approaches to the delivery of antibodies to their intracellular targets: transfection, cell-penetrating peptides, fragments of bacterial toxins, lipid-based molecules, physical methods (electroporation and microinjection). None of these methods have provided a complete solution for all the necessary stages of intracellular transport. In this review, we have analyzed different approaches intended for recombinant antibody delivery and discussed their limitations and pitfalls.

\section{ANTIBODIES AS PROSPECTIVE TOOLS FOR UNDRUGGABLE TARGETS}

One possible way to engage in the therapy of intracellular "undruggable" protein targets is the use of antibodies. Antibodies could be raised against different protein antigens, including those with flat contact surfaces that are not druggable via small-molecule approaches. Since the first therapeutic antibody entered the market in 1986, various antibodies against different targets have been developed and more than 60 antibody therapeutics have been approved (Carter and Lazar, 2018). The major advantages of antibodies are supreme specificity and affinity for a target, which make them invaluable basic experimental tools, as well as the standard of care, for indications, such as rheumatoid arthritis (Weinblatt et al., 2003; Smolen et al., 2017), psoriasis (Ratner, 2015), solid tumors (Slamon et al., 2011; Larkin et al., 2015; Roviello et al., 2017), and blood cancers (Coleman et al., 2016; Brown et al., 2017). The considerable success of antibody therapy in the clinic has sparked a major effort into antibody research, including the development of engineered humanized molecules with improved physicochemical properties and safety (Beck et al., 2010; Strohl and Strohl, 2012; Weiner, 2015; Elgundi et al., 2017). Similarly, recent large-scale antibody generation projects established a pipeline for the high-throughput development and validation of binder proteins for numerous possible targets (Colwill and Graslund, 2011; Landegren, 2016).

As a potent tool with wide applications, the antibodies can capture splice variants and proteins subjected to post-translational modifications, as well as different protein isoforms and conformational variants. For fundamental purposes, this approach might allow better clarification of the activity of intracellular proteins in their natural environment for better elucidation and validation of disease mechanisms. Furthermore, antibodies that can interact with a particular domain of a target protein are more specific than approaches such as gene knockout, transfection, and changes in gene 
expression. To date, most antibodies are limited to cell membrane targets (Scott et al., 2012; Carter and Lazar, 2018), such as receptors or secreted proteins, such as cytokines, growth factors, and hormones. The number of transmembrane and secreted proteins is estimated to be approximately 8000-9000 proteins (Miersch and Sidhu, 2016), which implies that two thirds of the proteome could be unlocked for antibody modulation in vivo. To this end, the antibody must be delivered inside the living cell.

\section{DERIVATIVES OF ANTIBODIES AND ANTIBODY-LIKE POLYPEPTIDES}

The features of antibodies, such as large size, complex architecture and molecular composition, and costly manufacturing, have catalyzed a significant research effort to finding alternative binder molecules based on smaller antibody fragments or alternative protein scaffolds. Thus, $150-\mathrm{kDa}$ multidomain antibodies produced in eukaryotic expression systems have inspired the search for smaller antibody fragments amenable for specific target recognition and suitable for less expensive production in Escherichia coli (Figure 1). The most common (Gebauer and Skerra, 2015), 26-kDa ScFv and $45-\mathrm{kDa} \mathrm{Fab}$, are characterized by lower expression costs but also by rapid clearance than the parent molecules. However, they still contain intradomain disulfide bonds, which hamper correct folding upon expression in E. coli. Some natural antibodies (for example, those discovered in camels) contain $15-\mathrm{kDa}$ heavy-chain only antibodies lacking a disulfide bond (dsAb or VHH, also known as Nanobodies ${ }^{\circledR}$ ) (Hamers-Casterman et al., 1993). VHH antibodies are possible alternatives to conventional antibodies, which have good stability, solubility, and expression yields. In addition, dozens of antibody-mimic types have been described through advances in combinatorial selection techniques (Binz et al., 2005; Mintz and Crea, 2013; Skrlec et al., 2015). The most advanced clinical stage scaffolds (Wurch et al., 2012; Gebauer and Skerra, 2015; Vazquez-Lombardi et al., 2015) are a 10-kDa monobody (Adnectin) based on the human fibronectin FN3 domain, a 6-kDa affibody based on the Z-domain of staphylococcal protein A, 20-kDa anticalin derived from human lipocalins, and the 14- to $21-\mathrm{kDa}$ designed-ankyrinrepeat proteins (DARPins) engineered consensus sequence based on ankyrin repeat proteins. Alternative antibody scaffolds are much smaller in size, and combine a disulfide-free single domain with sufficient affinity and easy production in different hosts. A feature of small-size alternative binders and antibody fragments is their short circulation time in the blood, which may be advantageous for diagnostic functionality. Additional opportunities are presented by a class of bispecific antibodies able to recognize simultaneously two different epitopes on the same or different antigens. This concept was proposed for classical immunoglobulins G (IgGs) in 1983 (Milstein and Cuello, 1983) but has been challenging owing to the complexities of their production. Expansion of antibody fragments could push this field forward, which has become a "hot topic" in research since

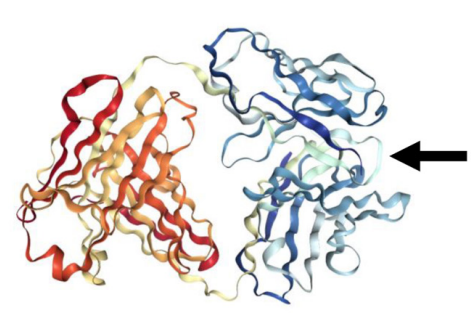

Fab

PDB: 5X4G

$\sim 55 \mathrm{kDa}$

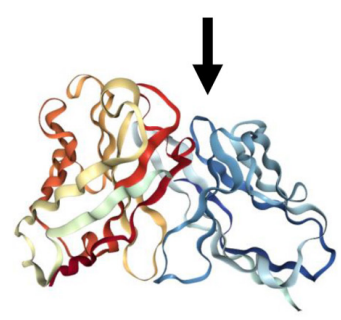

ScFv

PDB: 4P49

$\sim 28 \mathrm{kDa}$

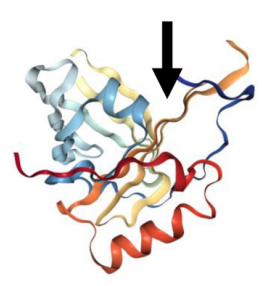

Anticalin

PDB: $1 \mathrm{KXO}$

$\sim 20 \mathrm{kDa}$

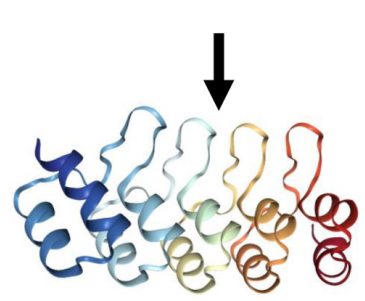

DARPin

PDB: 4J7W

$\sim 15 \mathrm{kDa}$

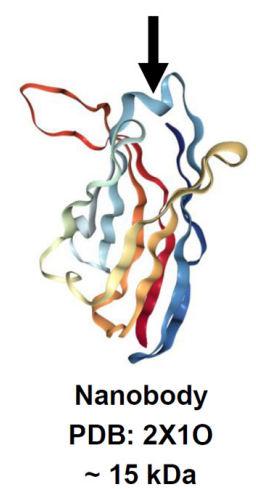

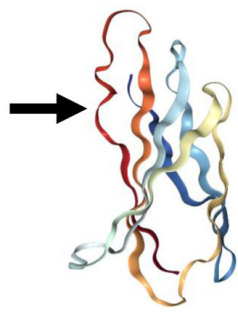

Monobody
PDB: 5DC0
$\sim 10 \mathrm{kDa}$

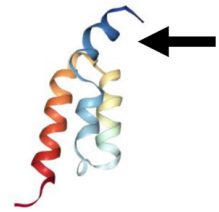

Affibody

PDB: 2KZI

$\sim 6 \mathrm{kDa}$

FIGURE 1 | Structure of antibody fragments and alternative antibody scaffolds described in this review. Structures were generated by using NGL Viewer (doi: 10.1093/nar/gkv402). Rainbow color scheme: blue is the N-terminus and red is the C-terminus. Arrows depict antigen binding sites. 
2010, with more than 60 molecules in development (Del Bano et al., 2015; Godar et al., 2018).

\section{INTERNALIZATION OF ANTIBODIES INTO CELLS VIA NORMAL AND PATHOLOGICAL PROCESSES}

The interior part of a cell is not a single cavity inside the cell plasma membrane, but a sophisticated diversity of compartments separated by intracellular membranes. Therefore, the detection of a substance within a cell can mean quite different things, and the terms "intracellular transport" or "transport into a cell" for an antibody, as well as for any macromolecules, may also have different meanings. In many cases, this transport is limited to entrapment within the compartments of the endocytosis/transcytosis pathway when molecules entering a cell remain within closed membrane formations, from which there were three common pathways: a recirculation path back to the external environment; transcytosis to the other side of the cell; and a degradation path through the lysosomes. However, the most in-demand approach is the transport of antibodies into the cytosol, which may or may not be followed by their subsequent transport to other compartments (e.g., the nucleus), where the majority of potential therapeutic targets are concentrated.

Although it is generally believed that antibodies do not penetrate the plasma membrane, there is a considerable data pool that illustrates the presence of various antibodies within cells (Alarcon-Segovia et al., 1979; Alarcon-Segovia et al., 1996; Reichlin, 1998; Weisbart et al., 1998; Ruiz-Arguelles et al., 2003; Kim J.S. et al., 2015; Weisbart et al., 2015; Noble et al., 2016) as a result of antigen-driven or antibody-driven cell entry of the free antibody or antibody-antigen complex.

Antigen-driven cell entry can be observed for antibodies bound to antigens of several viruses and bacterial toxins that naturally penetrate into cells, mainly through endocytosis followed by subsequent endosomal escape to the cytosol, where they are destroyed by the intracellular Fc-receptor TRIM21 and direct intracellular pathogens into proteasomes (Mallery et al., 2010; Watkinson et al., 2014). TRIM21 is a widely expressed E3 ligase (Yoshimi et al., 2009) recognizing the antibody Fc domain with high affinity (600 pM after TRIM21 dimerization) (Mallery et al., 2010). The function of this system is to protect the cell against intracellular pathogens, such as viruses and bacteria, internalized with attached host antibodies (McEwan et al., 2013). The delivery of an antibody against a particular cell protein could mobilize the TRIM21 system to act against the endogenous proteins (Clift et al., 2017). Nevertheless, to take advantage of the TRIM21 system for the disruption of a particular protein in target cells seems to be a tall order, requiring the delivery of full-sized-antibodies inside living cells.

The intracellular localization of antibodies and their complexes with antigens that enter the cell by antibody-driven mechanisms [e.g., via several types of Fc-receptors (Nimmerjahn and Ravetch, 2008)] is initially normally limited to endocytic vesicles, such as endosomes or phagosomes. Subsequent antibody recycling through neonatal Fc receptors FcRn
(Ghetie and Ward, 2002; Ward et al., 2015), and transcytosis or degradation in lysosomes, also prevent antibodies from crossing the membrane and entering the cytosol. However, a recently elucidated mechanism of antigen presentation in dendritic cells, including Sec61-mediated antigen transport from endosomes in the cytosol for cross-presentation (Zehner et al., 2015), might allow the antibody, if already bound to antigen when internalized by the dendritic cell, to enter the cytosol.

As already noted above, the property of most antibodies that limits their applications to targeting extracellular proteins is their inability to cross cellular membranes to reach the cytosol and compartments such as the nucleus. One exception is the small subset of naturally occurring mouse and human autoantibodies that target host self-antigens during autoimmune diseases, such as multiple sclerosis (Douglas et al., 2013), systemic lupus erythematosus, and Sjogren syndrome (Ruiz-Arguelles et al., 2003; Rhodes and Isenberg, 2017) and artificial ones based on them (Jang et al., 2009; Weisbart et al., 2012; Choi et al., 2014). It has been reported that these autoantibodies possess an intrinsic ability to penetrate living cells and capture intracellular and intranuclear antigens, such as DNA, histones, ribosomal protein P, nuclear ribonucleoproteins, and others (Noble et al., 2016). Penetration into different types of cells has been described, but it was not antibody isotype-specific (Rhodes and Isenberg, 2017). In some cases, autoantibody internalization causes cell apoptosis (Sun et al., 2001; Rivadeneyra-Espinoza and RuizArguelles, 2006; Douglas et al., 2013) or cytokine release (Sun et al., 2000), which contributes to the inflammation associated with autoimmunity. Several mechanisms of internalization have been suggested, including the interactions of basic residues in the complementarity-determining region of autoantibodies with a negatively charged cell surface (Song et al., 2008), Fc receptor-mediated entry (Lisi et al., 2007), or heparin sulfate proteoglycan-mediated clathrin-dependent endocytosis (Choi et al., 2014), or via caveolae/raft-dependent endocytosis (Jang et al., 2009) of nucleoside transporter ENT2 (Hansen et al., 2007). The ability of some autoantibodies to cross the cell membrane was explored with 3D8 and 3E10 anti-DNA autoantibodies as delivery vectors for attached payloads such as nanoparticles (Chen et al., 2016) and proteins (Weisbart et al., 2003, 2004a; Hansen et al., 2006; Hansen et al., 2007). However, a deep understanding of the penetration mechanisms of autoantibody and the extent to which they may be modified is still lacking.

\section{STRATEGIES FOR INTRACELLULAR TARGETING OF ANTIBODIES, THEIR MIMICS, AND DERIVATIVES}

Except for the above-described, relatively limited group of antibodies that can penetrate cell membranes, most antibodies targeted to promising intracellular targets do not demonstrate cell-penetrating ability, making their delivery inside a cell a key bottleneck. Various technologies have been developed and tested to accomplish this task; some success has occurred. Those strategies can be grouped into several major classes: direct physical delivery, direct 
intracellular expression, fusion with the part of internalizing autoantibodies responsible for their intrinsic ability to enter the cells, the use of protein-transduction domains or their mimics, and the use of various nanoparticle carriers (including inorganic nanoparticles, liposomes, polymersomes, and viral envelopes). These main approaches are schematically presented in Figure 2.

\section{Physical Delivery}

One of the most straightforward and oldest strategies of intracellular antibody delivery is their direct physical transfer into the target cell; the predominantly exploited methods include electroporation (Chakrabarti et al., 1989; Lukas et al., 1994; Marrero et al., 1995; Baron et al., 2000; Rui et al., 2002; Freund et al., 2013; Marschall et al., 2014; Desplancq

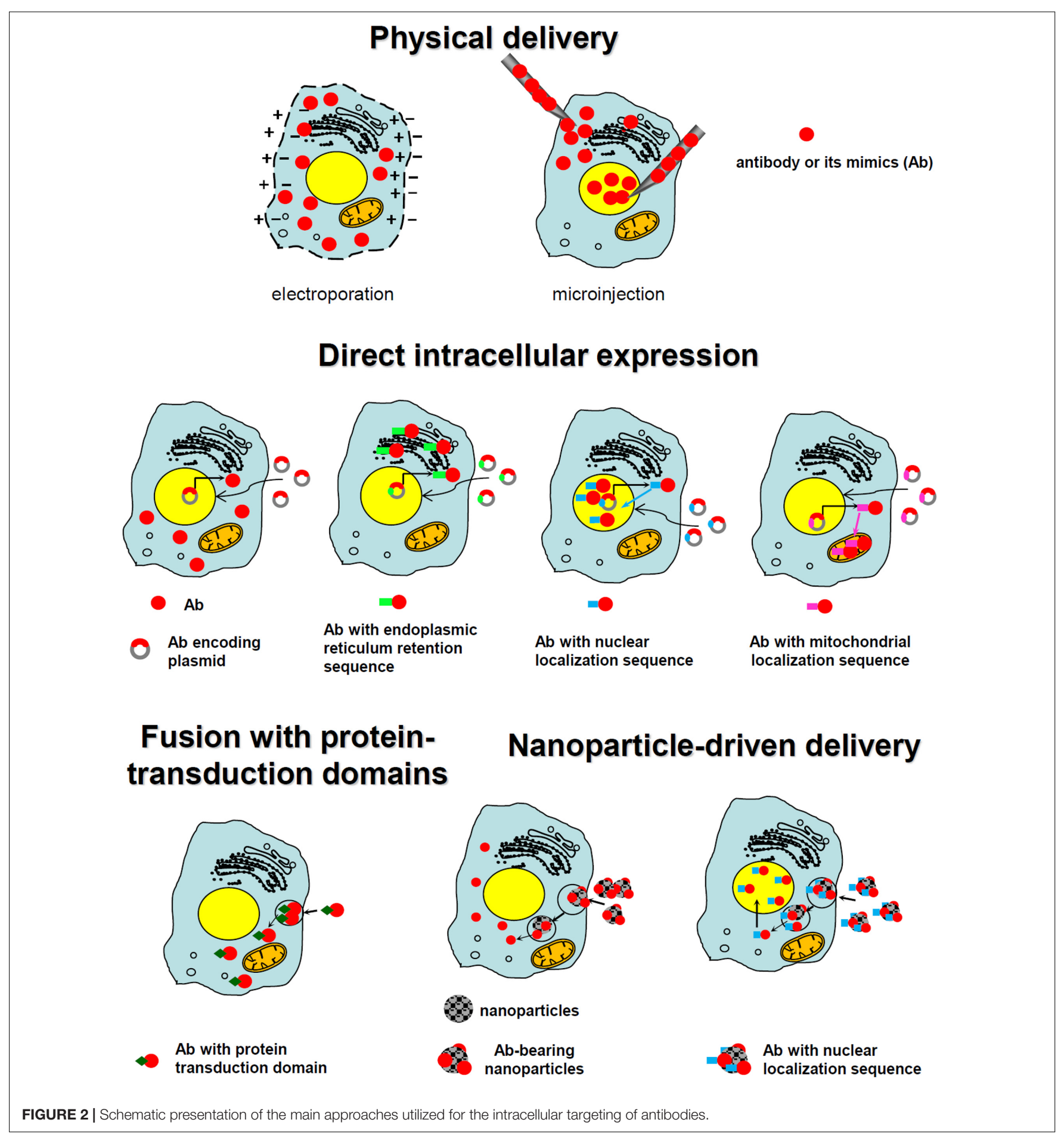


et al., 2016; Conic et al., 2018) and microinjection (Scheer et al., 1984; Riabowol et al., 1988; Lessman et al., 1997; Gire and Wynford-Thomas, 1998; Ma et al., 1999; Keppeke et al., 2015; Dixon et al., 2017). These methods are successfully used in protein functional studies, although a rising number of studies aimed at establishing an in vivo electroporation technique (Aihara and Miyazaki, 1998; Lohr et al., 2001; Heller and Heller, 2010), primarily for nucleic acid delivery, including encouraging clinical trials (NCT01440816) (Daud et al., 2008) makes their practical implementation theoretically conceivable for some local applications. Recently, several new physical delivery approaches have been recruited for intracellular antibody delivery. For example, anti-E6 HPV 16 oncoprotein antibody delivered by sonoporation, which is based on the simultaneous use of high intensity focused ultrasound with microbubbles, was shown to restore p53 expression, whose degradation is promoted by the E6 oncoprotein (Togtema et al., 2012). A new sophisticated method called the biophotonic laser-assisted surgery tool, relying on laser-induced cavitation bubbles for the creation of transient plasma membrane pores, was demonstrated to deliver different cargoes, including antibodies, into cells (Wu et al., 2015). In addition, an approach utilizing rapid cellular membrane deformation (microfluidics) was used for the delivery of a range of different macromolecules, including anti-tubulin antibodies, into live $\mathrm{HeLa}$ cells (Sharei et al.,
2013). All these physical delivery methods offer the advantage of direct antibody delivery inside the cytosol with the ability to target other compartments (e.g., the nucleus) upon the attachment of the specific localization signal, as shown for the nuclear delivery of anti-PCNA antibody conjugates with NLS delivered into the cells via electroporation (Freund et al., 2013). Possible limitations of these methods include a lack of cellspecificity, in addition to rather difficult in vivo, and difficulties in clinical translation. Examples of different approaches to intracellular physical delivery of antibodies are presented in Table 1.

\section{Direct Intracellular Expression}

In addition to the physical delivery described above, a well-established straightforward method for intracellular antibody delivery is the so-called intrabody technique. An intrabody is an antibody or its derivative produced within the same cell where the antigen is located. Intrabody expression can be achieved by cell transfection with a plasmid or virus carrying the gene encoding the antibody or its fragment. This technology has become more attractive since one of the pioneering proof-of-principle works demonstrating the inhibition of alcohol dehydrogenase I in Saccharomyces transfected with cDNAcoding antibody was published in 1988 (Carlson, 1988). The advantages of this approach are the direct expression within the cell and relatively easy direction of intrabody to the desired cell

TABLE 1 | Examples of physical delivery of antibodies inside cells.

\begin{tabular}{|c|c|c|c|}
\hline Delivery approach & Antibody type & Targeted antigen & Reference \\
\hline Microinjection & monoclonal antibody (mAb) (lgG) & $\alpha$-tubulin & Lessman et al., 1997 \\
\hline Microinjection & $\begin{array}{l}\text { polyclonal antibody labeled with Alexa } \\
\text { Fluor } 488\end{array}$ & $\begin{array}{l}\text { inosine- } 5^{\prime} \text {-monophosphate } \\
\text { dehydrogenase } 2\end{array}$ & Keppeke et al., 2015 \\
\hline Microinjection & mAbs & $\mathrm{N}$-terminal transactivation region of p53 & Gire and Wynford-Thomas, 1998 \\
\hline Microinjection & four different mAbs & $\alpha-p 21$ & Ma et al., 1999 \\
\hline Microinjection & polyclonal antibody & fos & Riabowol et al., 1988 \\
\hline Microinjection & polyclonal antibody (IgG) & actin & Scheer et al., 1984 \\
\hline $\begin{array}{l}\text { Microinjection into either the nuclei or } \\
\text { cytoplasm }\end{array}$ & $\begin{array}{l}\text { NLS-conjugated polyclonal antibody } \\
\text { (lgG) }\end{array}$ & lamin A/C histone-binding site & Dixon et al., 2017 \\
\hline Electroporation & two different mAbs & bovine asparagine synthetase & Chakrabarti et al., 1989 \\
\hline Electroporation & mAbs & $\begin{array}{l}\text { proliferating cell nuclear antigen (PCNA) } \\
\text { DNA polymerase } \alpha, \mathrm{HPV} 16 \text { E6 } \\
\text { oncogene }\end{array}$ & Freund et al., 2013 \\
\hline Electroporation & $\mathrm{mAb}$ and Fab & PCNA DNA polymerase alpha & Desplancq et al., 2016 \\
\hline In situ electroporation & mAbs & $\begin{array}{l}\text { TF-1 apoptosis-related gene } 19 \\
\text { (TFAR19), or Programmed Cell Death } \\
\text { 5(PDCD5) }\end{array}$ & Rui et al., 2002 \\
\hline Electroporation & scFv-Fc & myosin, tubulin & Marschall et al., 2014 \\
\hline Electroporation & polyclonal antibody & pp60c-src & Marrero et al., 1995 \\
\hline Electroporation & $\mathrm{mAb}$ & cyclin D1 & Lukas et al., 1994 \\
\hline Electroporation & $\begin{array}{l}\text { mAbs and Fabs labeled with Alexa } \\
\text { Fluor } 488\end{array}$ & $\begin{array}{l}\gamma \mathrm{H} 2 \mathrm{AX}, \alpha \text {-tubulin, heptapeptide repeats } \\
\text { of nonphosphorylated C-terminal } \\
\text { domain of the largest subunit of RNA } \\
\text { Pol II, TATA binding protein (TBP), } \\
\text { TBP-associated factor } 10\end{array}$ & Conic et al., 2018 \\
\hline Microfluidics & mAb labeled with Alexa Fluor 488 & tubulin & Sharei et al., 2013 \\
\hline Sonoporation & $\mathrm{mAb}$ & E6 HPV 16 oncoprotein & Togtema et al., 2012 \\
\hline Laser-induced cavitation bubbles & mAb labeled with Alexa Fluor 488 & $\alpha$-tubulin & Wu et al., 2015 \\
\hline
\end{tabular}


compartment where the specific antigen should be bound (e.g., membrane or secreted protein in the ER or nuclear protein in the nucleus). The latter is usually achieved by the attachment of a targeting sequence. The targeting of intrabodies to be retained in the ER appears to be the most straightforward approach, enabling their maturation and folding in the native environment.

A secretory signal peptide targets intrabody to the ER lumen, and ER retention by KDEL (Lys-Asp-Glu-Leu) (or similar) sequence introduced into the C-terminus of the intrabody traps the intrabody-antigen complex within the ER-Golgi complex (Hammond and Helenius, 1994). These types of intrabodies do not need to be strictly neutralizing to exert their knockdown functions, as the mere act of retention of secretory or membrane proteins within the ER knock down their functionality. In contrast, intrabodies aimed at cytosolic, nuclear, or mitochondrial antigens require much more precise tuning to provide for their appropriate folding within the cytosol (Hammond and Helenius, 1994; Marschall and Dubel, 2016). To overcome this limitation, many different strategies for the generation and/or selection of suitable antibodies for cytosolic expression have been developed. These approaches include: use of single-domain antibody variants [camelid $\mathrm{VHH}$, shark-derived variable new antigen receptors, or variable domain of the heavy chain (VH) or light chain (VL) selected from human antibodies] (Boldicke, 2017); fusion with different protein domains [maltose binding protein (Bach et al., 2001), Fc-domain (Strube and Chen, 2004), proteasome-targeting PEST motif (Joshi et al., 2012), and others (Jurado et al., 2006); grafting of complementary determining regions (Donini et al., 2003); construction and selection of intrabodies lacking S-S bonds (Colby et al., 2004; Cetin et al., 2017); numerous eukaryotic in vitro selection-based strategies aimed at isolating a functional and soluble antibody fragment (Guglielmi et al., 2011; Matz et al., 2014; Lee et al., 2016) and even electrostatic manipulation via the introduction of negative charges (Kvam et al., 2010; Liu et al., 2015). In addition to direct interaction with the antigen located in the cytosol, simple fusion with an appropriate signal peptide (Biocca et al., 1991) can redirect intrabodies expressed in the cytosol to bind the antigens within the cell nucleus (Verheesen et al., 2006) or mitochondrion (Biocca et al., 1995).

As phage display technology allows rapid and relatively easy generation of antibodies to almost any antigen of interest (Vaughan et al., 1996; Colwill and Graslund, 2011; Frenzel et al., 2017), intrabodies aimed at many different proteins, including their splice variants and specific post-translational modification sites (Koo et al., 2014; Chirichella et al., 2017), have been developed and shown to be rather efficient in vitro and sometimes in vivo (Amici et al., 2016). The most widely utilized targets include cancer-linked antigens (Van Impe et al., 2013; Chan et al., 2016; Alirahimi et al., 2017; Amici et al., 2016), neurodegenerative-disease-related antigens (Lynch et al., 2008; Joshi et al., 2012; Butler and Messer, 2011), toxins (Tremblay et al., 2010; Alzogaray et al., 2011), viral infection (e.g., HIV or HCV) - related antigens (Matz et al., 2014; Boons et al., 2014; Ashour et al., 2015; Amici et al., 2016), and miscellaneous antigens, mostly for protein function studies, within the cell (Van Audenhove et al., 2013). The therapeutic potential of intrabodies against cancer (Amici et al., 2016), Huntington's disease (Southwell et al., 2009), and Alzheimer's disease (Ryan et al., 2010) has been already demonstrated in mouse models of these diseases. Moreover, in a phase I clinical trial conducted in 2000 (Alvarez et al., 2000), the feasibility of adenoviral-mediated gene therapy using an anti-erbB-2-directed intrabody in the context of human ovarian cancer was shown: the authors reported anti-erbB-2 scFv-encoding gene expression measured by polymerase chain reaction and real-time polymerase chain reaction in most patients with very limited toxicity. However, contrary to the effects demonstrated by an anti-erbB2-directed intrabody in animal studies (Deshane et al., 1995), no dramatic clinical benefit was observed in this trial, leaving much room for the improvement of this strategy.

Thus, the attractive potential therapeutic use of intrabodies still has unresolved issues; the major issues are finding an efficient and safe DNA transfection method in vivo and insufficient tissue specificity. The other issues include the delayed onset of the effect, uncertain duration and level of expression, and whether the transformation is transient or permanent (especially when using such vectors as polyplexes, liposomes, adenoviruses). However, extensive research into the development of promising new nucleic acid delivery systems, including tissue-specific variants (Durymanov et al., 2013; Mann and Kullberg, 2016; Kim et al., 2017) for various gene therapy applications have led to a number of clinical trials and a few already clinically approved approaches (Pearson et al., 2004; Yla-Herttuala, 2012; Buning, 2013; Zhang W.W. et al., 2018) favor the introduction of intrabody-based therapy to the clinic.

\section{Fusion With Part of Internalizing Autoantibodies Responsible for Their Intrinsic Ability to Enter Cells}

Although the intrabody approach relies on straightforward intracellular expression within the same antigen-expressing cells, another strategy is based on the use of the intrinsic ability of several naturally occurring autoantibodies (see Section "Internalization of Antibodies Into Cells Via Normal and Pathological Processes") to enter the cells. The most straightforward pathway utilizes the recently discovered potential of a subset of cell and nuclear penetrating lupus erythematosus anti-DNA autoantibodies to serve as therapeutic agents targeted toward DNA repair-deficient malignancies (Hansen et al., 2012; Noble et al., 2014, 2015). Specifically, the lupus erythematosus anti-DNA autoantibodies 3E10 (Hansen et al., 2012) and their more potent divalent mutants (Noble et al., 2015), including humanized and re-engineered ones (Rattray et al., 2018), as well as the nucleolytic autoantibody 5C6 (Noble et al., 2014) were shown to bind DNA and either inhibit key steps in DNA repair or damage single-stranded DNA in a manner, making them selectively lethal to cancer cells with defective homology-directed repair of DNA double-strand breaks.

A more flexible and universal approach recruits the fragments responsible for cell entry of those cell penetrating autoantibodies for fusion with antigen-recognizing parts of the antibody of choice. A series of articles (Weisbart et al., 2004b, 2012; Choi 
et al., 2014; Kim J.S. et al., 2016; Shin et al., 2017) have reported proof-of-principle of the feasibility of this approach to the demonstration of significant antitumor effects in vivo. In particular, humanized VL of lupus erythematosus autoantibody m3D8, with its ability to penetrate the cell and localize in the cytosol, has been engineered into different human IgGs to give so-called cytotransmabs capable of targeting an intracellular antigen of choice within the cytosol (Choi et al., 2014). Based on this strategy, the human IgG1 format antibody named iMab RT11-i containing m3D8 humanized VL targeted to the cytosolic activated GTP-bound form of oncogenic Ras mutants has been developed. Decorated with tumor-homing integrin binding RGD10 cyclic peptide, this iMab inhibited the growth of oncogenic Ras-mutated tumor xenografts in mice, but not wildtype Ras-harboring tumors (Shin et al., 2017), demonstrating the feasibility and potential of this approach for the cytosolic delivery of antibodies. Nuclear delivery of antibodies has been demonstrated by using a bivalent scFv derivative of cell and nuclear penetrating autoantibody 3E10 fused to an anti-MDM2 antibody, which impaired the growth of melanoma cells and melanoma xenografts sensitive to MDM2 inhibition (Weisbart et al., 2012).

\section{Protein-Transduction Domains or Their Mimics}

Contrary to the limited number of studies utilizing the part of internalizing autoantibodies responsible for their intrinsic ability to enter the cells, a somewhat similar approach relying on fusion to protein transduction domains, or CPPs, is a widely utilized technique to shuttle various cargos (proteins, plasmid DNA, RNA, oligonucleotides, liposomes, imaging agents, and anti-cancer drugs) into living cells. Since the discovery of the first and prototypical HIV 1 trans-activating (TAT) protein, capable of cell membrane penetration (Green and Loewenstein, 1988; Frankel and Pabo, 1988) in 1988, a wide variety of CPPs and some of their mimics was derived and recruited for the intracellular delivery of various agents for research studies or potential therapeutic applications (Kristensen et al., 2016; Bolhassani et al., 2017; Borrelli et al., 2018), with a few reaching clinical trials to date (NCT01975116, NCT00914914). Unsurprisingly, this promising strategy has also been attempted to enhance intracellular antibody delivery, which has led to cell penetrating TransMabs (Muller et al., 2005) or transbodies. An early study (Anderson et al., 1993), revealing enhanced cell retention and internalization of Fab fragments decorated with a TAT protein-derived peptide, was followed more than a decade later by a set of articles demonstrating that antibody-based fusion proteins containing a short membrane transport-facilitating peptide were transported into the cells and bound to intracellular structures (Zhao et al., 2001) and that anti-caspase-3 antibody based TransMabs were able to inhibit apoptosis (Zhao et al., 2003) in cells. Subsequently, this approach gained popularity and the number and use of CPP-conjugated whole antibodies, and their derivatives, started to increase (Mie et al., 2003; Cohen-Saidon et al., 2003; Ohara-Imaizumi et al., 2004; Shin et al., 2005; Chen and Erlanger, 2006; Theisen et al., 2006; Hu et al., 2007; Avignolo et al., 2008); see Table 2 for examples. Recently, a transbody based on mAbs against human $\mathrm{HBcAg}$ coupled with the TAT protein transduction domain was demonstrated to be effective in vivo ( $\mathrm{Li}$ et al., 2017).

However, there are two main limitations to be addressed when using this strategy. The first stems from the pool of data that demonstrate entrapment of the internalized CPPs (Richard et al., 2003) and CPP-conjugates inside endocytic vesicles (Fischer et al., 2006; Benavent Acero et al., 2014; Marschall et al., 2014), which has raised the question as to whether CPPs and CPP-conjugated macromolecules, including transbodies, are able to be released from the endosomes efficiently, making efficient endosomal escape one of the limitations of this approach (El-Sayed et al., 2009). The insertion of an additional endosomolytic moiety was suggested to improve the situation (Rinne et al., 2007; Liou et al., 2012). A recent study reported an efficient endosomal escape of an antibody co-delivered with an endosomolytic peptide derived from the cationic and membrane-lytic spider venom peptide M-lycotoxin (Akishiba et al., 2017). An approach utilizing light-controlled endosomal photosensitizer-driven escape of the construct based on an anti-Ki67 mAb decorated with CPP Pep-1 co-delivered with photosensitizer was revealed as an effective strategy to facilitate the endosomal escape of antibodies (Wang et al., 2015).

Another limitation of CPP-based technology, including transbodies, may be the absence of tissue and cellular specificity. Although, in the case of transbodies, cell-specific action can be reached on the antigen level, the problem of unnecessary unspecific delivery to cells remains, but may be solved by using some cell-homing CPPs (Svensen et al., 2012) or the addition of a cell-targeting ligand to a transbody. For example, a fusion of anti-mutated K-ras scFv and cancer-cell specific CPP BR2 demonstrated significant and cancer-cell-selective effects in vitro (Lim et al., 2013).

\section{Nanocarriers}

Nanocarrier-driven targeted intracellular delivery of different payloads is a widespread strategy that has the following advantages: allows systemic delivery of a relatively large amount of cargo with reduced cargo-related side effects; lowers off-target organ toxicity; enables the possibility of sustained release; and shields the cargo from premature enzyme degradation (Sousa et al., 2017). Moreover, nanocarriers permit relatively easy decoration with functional (e.g., cell-targeting) moieties, which, in contrast to direct antibody modification, cannot hamper their reactivity. Thermosensitive (Fathi et al., 2018), enzyme-sensitive (Aluri and Jayakannan, 2017), pH-sensitive (Braunova et al., 2017), light-responsive (Kim H. et al., 2016), and combo-stimuli-responsive (Kashyap et al., 2016) nanocarriers can be easily designed to provide a controlled payload release in response to thermal (body, increased tumor temperature, or localized heating), specific enzymatic (e.g., tumor microenvironment or intracellular enzymes) and specific $\mathrm{pH}$ microenvironments (e.g., acidic tumor microenvironment or acidifying endocytic vesicles) as well as to external light exposure or any combination of these.

Various types of nanocarriers (see Table 3 for examples), including inorganic nanoparticles (Chiu et al., 2016; Song et al., 
TABLE 2 | Examples of intracellular delivery of CPP-fused antibodies.

\begin{tabular}{|c|c|c|c|}
\hline CPP or their mimics used for fusion & Antibody type & Targeted antigen & Reference \\
\hline TAT peptide & Fab & $\begin{array}{l}\text { melanoma-associated antigen, pan-carcinoma } \\
\text { antigen }\end{array}$ & Anderson et al., 1993 \\
\hline Membrane transport sequence & $\lg G$ & human B-cell lymphoma, mouse B-cell tumor & Zhao et al., 2001 \\
\hline $\begin{array}{l}\text { Poly-L-arginine (average molecular weight } \\
\text { 10,750, ca. } 68 \text { residues) }\end{array}$ & $\mathrm{mAb}$ & HIV-1 Gag, fullerene and others & Chen and Erlanger, 2002 \\
\hline TAT peptide & scFv & $\mathrm{Bcl}-2$ & Cohen-Saidon et al., 2003 \\
\hline TAT fusion protein A & $\lg G$ & - & Mie et al., 2003 \\
\hline TAT peptide & $\mathrm{mAb}$ & syntaxin 1 & Ohara-Imaizumi et al., 2004 \\
\hline $\begin{array}{l}\text { Membrane-translocating sequence (MTS) from } \\
\text { Kaposi fibroblast growth factor }\end{array}$ & scFv & Akt & Shin et al., 2005 \\
\hline Polyarginine 68R & $\mathrm{mAb}$ & cyclin D1 & Chen and Erlanger, 2006 \\
\hline TAT peptide & scFv & HIV-1 TAT-protein & Theisen et al., 2006 \\
\hline TAT peptide & $\lg G$ & p21 WAF-1/Cip-1 & Hu et al., 2007 \\
\hline Antennapedia protein transduction domain & scFv & C-Myc & Avignolo et al., 2008 \\
\hline $\begin{array}{l}\text { Penetratin (PEN) of the Drosophila } \\
\text { homeodomain }\end{array}$ & scFv & M1 matrix protein of influenza A virus & Poungpair et al., 2010 \\
\hline BR2 (17aa peptide) & scFv & K-RAS & Lim et al., 2013 \\
\hline TAT peptide & $\mathrm{Fab}$ & HIV-1 protein Rev & Zhuang et al., 2014 \\
\hline 3R-Based lipophilic protein A-modified polymer & $\mathrm{mAb}$ & nuclear pore complex & Itakura et al., 2015 \\
\hline Anthrax toxin protective antigen & $\begin{array}{l}\text { affibody, DARPin, } \\
\text { monobody, protein } \\
\text { GB1 }\end{array}$ & $\begin{array}{l}\text { Src homology } 2 \text { domain of the oncoprotein } \\
\text { Bcr-Abl }\end{array}$ & Liao et al., 2014 \\
\hline Fc-binding peptide (FcBP)-TAT conjugate & $\lg G$ & - & Kang et al., 2015 \\
\hline Eight different CPPs & $\lg G$ & HIV-1 p24 protein & Ali et al., 2016 \\
\hline $\begin{array}{l}\text { GET: membrane-docking peptide to heparan } \\
\text { sulfate glycosaminoglycans (GAGs) fused with } \\
\text { a PTD (peptide P21 and 8R) }\end{array}$ & $\lg G$ & - & Dixon et al., 2016 \\
\hline Nona-arginine (R9) & scFv & $(\mathrm{NS} 3 / 4 \mathrm{~A})$ of $\mathrm{HCV}$ & Jittavisutthikul et al., 2016 \\
\hline Nona-arginine (R9) & scFv & Ebolavirus VP40 & Teimoori et al., 2016 \\
\hline $\begin{array}{l}\text { Protein transduction domain mimics } \\
\text { MePh13-b-dG5 (P13D5) }\end{array}$ & $\lg G$ & phosphorylated protein kinase C $\theta$ (Thr538) & Ozay et al., 2016 \\
\hline $\begin{array}{l}\text { Mutated several amino acid residues on the } \\
\text { surface of the proteins to basic residues, } \\
\text { resulting in net positive charges of }+14 \text { and } \\
+15\end{array}$ & nanobodies & $\begin{array}{l}\text { green fluorescent protein (GFP), HER2, and } \\
\beta \text {-lactamase }\end{array}$ & Bruce et al., 2016 \\
\hline Cyclic R10 (cR10) peptide & nanobodies & GFP & Herce et al., 2017 \\
\hline Nona-arginine (R9) & ScFv & (NS5A) of $\mathrm{HCV}$ & Glab-Ampai et al., 2017 \\
\hline TAT peptide & $\mathrm{mAb}$ & $\mathrm{HBcAg}$ & Li et al., 2017 \\
\hline $\begin{array}{l}\text { Co-administration with endosomolytic peptides } \\
\text { derived from the cationic and membrane-lytic } \\
\text { spider venom peptide M-lycotoxin }\end{array}$ & $\lg G$ & - & Akishiba et al., 2017 \\
\hline TAT peptide & $\lg \mathrm{G} 1 \mathrm{mAb}$ & Hepatitis B virus $X$ protein & Zhang J.F. et al., 2018 \\
\hline Nona-arginine (R9) & HuscFvs & $\begin{array}{l}\text { interferon inhibitory domain of the VP35 protein, } \\
\text { a multifunctional virulence factor of Ebola virus }\end{array}$ & Seesuay et al., 2018 \\
\hline Cell-penetrating poly(disulfide)s & IgG labeled with Cy5 & - & Qian et al., 2018 \\
\hline
\end{tabular}

2016; Amornwachirabodee et al., 2018), polymersomes (Liu et al., 2010; Tian et al., 2015), liposome-based nanocarriers (Chatin et al., 2015), as well as modified viral (Kondo et al., 2008) and virus-like particles (Abraham et al., 2016) have all been recruited for antibody intracellular delivery with reasonable success.

\section{Lipid-Based Nanocarriers}

Lipid-based nanoparticles are extensively used for the intracellular delivery of therapeutic proteins, including antibodies. Several cationic-lipid based nanocarriers (Dalkara et al., 2004; Courtete et al., 2007) have been proposed for the intracellular delivery of antibodies. For example, Courtete et al demonstrated that a lipid reagent for siRNA transfection could be successfully adjusted to give efficient anti-HPV16 E6 antibody delivery and resulted in the downregulation of this oncoprotein activity in vivo (Courtete et al., 2007).

\section{Polymer Based Nanocarriers}

Polymer based nanoparticles are another widely used approach for intracellular protein delivery. Several years 
TABLE 3 | Examples of intracellular delivery of antibodies by nanocarriers.

\begin{tabular}{|c|c|c|c|}
\hline Nanocarrier & Antibody type & Targeted antigen & Reference \\
\hline $\begin{array}{l}\text { IgG-lipopolyamine } \\
\text { dioctadecylglycylspermine complexes }\end{array}$ & $\lg G$ & $\beta$-actin, $\alpha$-tubulin & Dalkara et al., 2004 \\
\hline Cationic lipid-based complexes & $\mathrm{mAb}$ & HPV16 E6 oncoprotein & Courtete et al., 2007 \\
\hline TAT-HA2 decorated gold nanoparticles & glycosylated mAbs & actin & Kumar et al., 2007, 2008 \\
\hline $\begin{array}{l}\text { Protein A Z-subdomain dimer fused } \\
\text { with nucleocapsid protein incorporated } \\
\text { into hemagglutinating virus of Japan } \\
\text { envelope }\end{array}$ & $\lg G$ & $\alpha$-tubulin nuclear pore complex & Kondo et al., 2008 \\
\hline $\begin{array}{l}\text { Gold-coated iron oxide nanoparticles or } \\
\text { quantum dots decorated with } \\
\text { Streptococcal bacterial protein G fused } \\
\text { with TAT }\end{array}$ & $\mathrm{mAb}$ & mitochondria & Lim et al., 2009 \\
\hline Polymersomes & $\lg G$ & - & Liu et al., 2010 \\
\hline Polymersomes & $\lg G$ & $\begin{array}{l}\text { NF-кB and } \gamma \text {-tubulin, actin, Golgi } \\
\text { protein }\end{array}$ & Canton et al., 2013 \\
\hline Self-associated MAb nanoparticles & mAb bevacizumab & VEGF & Srinivasan et al., 2013 \\
\hline $\begin{array}{l}\text { Self-assembling } \\
\text { pyridylthiourea-modified } \\
\text { polyethylenimine nanoparticles }\end{array}$ & mAbs modified with NLS & $\begin{array}{l}\text { HPV- } 16 \text { viral E6 oncoprotein, } \\
\text { threonine- } 927 \text { phosphorylation site of } \\
\text { the EG5 kinesin spindle protein }\end{array}$ & Postupalenko et al., 2014 \\
\hline $\begin{array}{l}\text { Liposomes based on } \\
\text { guanidinium-cholesterol cationic lipid } \\
\text { BGTC combined to the colipid (DOPE) }\end{array}$ & $\mathrm{mAb}$ & cytokeratin8 & Chatin et al., 2015 \\
\hline $\begin{array}{l}\text { Polymersomes targeted to low density } \\
\text { lipoprotein receptor-related protein } 1 \\
\text { receptor }\end{array}$ & $\lg G$ & - & Tian et al., 2015 \\
\hline $\begin{array}{l}\text { Virus-like particles decorated with lgG } \\
\text { binding moiety }\end{array}$ & $\lg G$ & abrin, anti- $\alpha$-tubulin, HER2 & Abraham et al., 2016 \\
\hline Mesoporous silica nanoparticles & $\begin{array}{c}\text { chromobody: fluorescent } \\
\text { nanobodies conjugated with } \\
\text { fluorescent proteins or organic } \\
\text { dyes }\end{array}$ & GFP & Chiu et al., 2016 \\
\hline Polyion complex micelles & $\operatorname{lgG} F_{c}$ & nuclear pore complex & Kim A. et al., 2016 \\
\hline $\begin{array}{l}\text { Nanoparticles based on nanobodies } \\
\text { with sequence-defined } \\
\text { oligoaminoamides decorated with folic } \\
\text { acid }\end{array}$ & nanobodies & GFP & Roder et al., 2017 \\
\hline Calcium phosphate biomineralization & mAbs & $\begin{array}{l}\text { Dengue virus surface envelope } \\
\text { glycoprotein, Hemagglutinin (HA) } \\
\text { protein of Influenza A virus }\end{array}$ & Song et al., 2016 \\
\hline $\begin{array}{l}\text { Erythrocyte membrane coated } \\
\text { self-assembling nanoparticles }\end{array}$ & $\mathrm{mAb}$ & hTERT & Gao et al., 2017 \\
\hline $\begin{array}{l}\alpha \text {-helical peptide Hex nanocarrier } \\
\text { decorated with Aurein }\end{array}$ & $\lg G$ & $\begin{array}{l}\text { anti- } \beta \text {-tubulin or anti-nuclear pore } \\
\text { complex }\end{array}$ & Lim et al., 2017 \\
\hline Oxidized carbon black particles & $m A b$ & Dengue virus & Amornwachirabodee et al., 2018 \\
\hline
\end{tabular}

ago, polymer-based liposomes, called polymersomes (Discher et al., 1999) were shown to be effective for the cytosolic delivery of antibodies aimed at various intracellular antigens inside the cells, resulting in the respective epitope binding and subsequent biological effect (Canton et al., 2013) in different cell types, as no cell-specific moiety was required in this proof-of-principle study. A few years later, a sophisticated polymersome-based approach for cell-specific antibody delivery across the blood-brain barrier was developed (Tian et al., 2015). Polymersomes were decorated with Angiopep-2 peptide targeting low density lipoprotein receptor-related protein 1 receptor to yield dual functionality, as this receptor is associated with both endothelial transcytosis and endocytosis into the cells of the central nervous system. As a result, Angiopep-2-decorated polymersomes delivered IgGs into the central nervous system cell in vitro, efficiently crossed the blood-brain barrier, and co-localized with astrocytes, neurons, and glial cells in vivo (Tian et al., 2015); thus, this approach warrants further development.

\section{Inorganic Nanocarriers}

Inorganic nanoparticles composed of several inorganic materials have been used for the intracellular delivery of antibodies. For example, mesoporous silica nanoparticles functionalized with nitrilotriacetic acid-metal ion complexes for $\mathrm{pH}$-sensitive binding and release of the delivered His6-tagged chromobodies (anti-GFP fluorophore labeled nanobodies) exhibited the ability 
to deliver these chromobodies inside the cells (Chiu et al., 2016). A noticeable release of chromobodies to cytosol required the use of endosomal release triggers, of which chloroquine and dimethyl sulfoxide were the most effective ones, which may be unsuitable for practical use. Another group developed mAbs to anti-influenza $A$ and anti-Dengue viral proteins biomineralized with calcium phosphate, yielding sphere-like 130-150 nm nanoparticles, which, in contrast with native unmodified mAbs were able to enter the cells and co-localize with their antigens within the endosomal compartment. Moreover, the biomineralized mAb led to a significant reduction in the mortality of the infected mice compared with the corresponding naked mAb (Song et al., 2016). Both these nanoparticle-based delivery systems possessed difficulties in endosomal escape of the delivered antibody that necessitated the use of endosomal release triggers or were limited to antigens that are known to localize within the endosomes. An easy way to reach the cytosol is to enter the cell by a non-endocytosis-involving pathway, as recently demonstrated for oxidized carbon black nanoparticles, which are supposed to cause temporary disruption of the lipid bilayer and thus provide antibody delivery inside the cells via an electroporation-like mechanism (Amornwachirabodee et al., 2018). Another solution to facilitate the delivery of antibody-bearing nanoparticles into the cytosol been proposed by Lim et al. (2009), who decorated gold-coated iron oxide nanoparticles with IgG-binding streptococcal bacterial protein $G$ fused with TAT peptide for endosomal escape. The resulting functionalized magnetic nanoparticles loaded with anti-mitochondria $\mathrm{mAb}$ were able to enter the cell and reach mitochondria within HeLa cells (Lim et al., 2009). However, the efficiency of TAT peptide-mediated endosomal escape is supposed to be rather low (Richard et al., 2005); thus, in order to improve endosomal release, another group developed an approach that recruited gold nanoparticles decorated with TAT peptide fused with $\mathrm{pH}$-sensitive influenza virus hemagglutinin protein HA2; in this, the former moiety was responsible for cell-entry and the latter for the introduction of efficient endosomal release of the delivered anti-actin antibody (Kumar et al., 2007).

The main limitation of all these approaches is their non-specific action; however, this may be solved by additional inclusion of nanoparticles with a cell-homing moiety.

\section{Viral and Virus-Like Nanocarriers}

Being extensively used for gene delivery, viral-based vehicles have been recruited successfully for intracellular antibody delivery. Efficient entrapment of the antibody within these viral-based nanoparticles is often provided by the inclusion of Staphylococcus aureus protein A or its sub-domains capable of IgG binding (Kondo et al., 2008; Park et al., 2009; Abraham et al., 2016). A decade ago, a system based on a protein A Z-subdomain dimer fused with nucleocapsid protein incorporated into the envelope of hemagglutinating virus of Japan revealed the ability to efficiently incorporate IgGs and target them to the respective intracellular antigens (nuclear pore complex and $\alpha$-tubulin) (Kondo et al., 2008). Owing to the possible toxic and immunogenic issues connected with viral vectors of animal origin, intracellular antibody-delivering plant virus-like nanoparticles, which are considered to be nonpathogenic in humans, were recently developed (Abraham et al., 2016). Based on Sesbania mosaic virus coat protein modified with IgG binding protein A B-domain self-assembling virus-like particles, this platform for intracellular delivery of antibodies proved to be effective for intracellular delivery of three different mAbs, which exerted their biological effects owing to respective epitope binding (Abraham et al., 2016). Generally, owing to the high efficiency of antibody delivery across the membrane, combined with the high loading efficiency compared with most nanovehicles (e.g., inorganic nanoparticles or polymersomes), viral-based particle approaches will encourage new horizons of study in this field, especially if an additional ability to target only the specified cells can be introduced into this type of nanoparticle.

\section{Other Types of Nanocarriers}

A few self-assembled protein nanocarriers (Lim et al., 2017), polyion complex micelles (Kim A. et al., 2016), and pharmacokinetic improving erythrocyte membrane-coated mAb nanoparticles (Gao et al., 2017) have been developed, with some exhibiting encouraging results. For example, a self-assembled protein nanocarrier based on an $\alpha$-helical peptide self-assembling into a hexameric coiled-coil bundle fused with an Fc-binding Protein A fragment was recently developed. It was further decorated with an endosomolytic Aurein 1.2 sequence. This nanocarrier enabled a high antibody loading and efficient delivery into the cytosol (Lim et al., 2017). The authors proposed possible future modifications of this nanocarrier with cell specific targeting ligands to dramatically increase the attractiveness of this already promising nanovehicle.

\section{Strategies for Intracellular Targeting of Antibodies, Their Mimics, and Derivatives: Summary of the Limitations and Prospects}

Targeted intracellular delivery of antibodies can be aimed at the antigens localized in various intracellular compartments, predominantly the ER, cytosol, and nucleus. Examples of efficient antibody intracellular delivery approaches aimed at specified intracellular compartments are presented in Table 4, and the advantages and limitations of different approaches are summarized in Table 5. The ER is very easily targeted by intrabodies, as natural antibodies already contain a signal for secretion; thus, only the additional ER retention motif (KDEL, usually) should be encoded within the antibody gene to achieve delivery into the cell, where an intrabody is expressed. Cytosolic and nuclear antigens require more effort to achieve intrabody targeting, but are still vastly applicable. The main problem with regard to the use of intrabodies is the requirement of a safe, efficient, and cellspecific gene delivery method for their in vivo use. The targeted delivery of the antibodies themselves inside the cell from the outside seems to lack many of the safety parameters associated with gene delivery, but narrows the variety of intracellular compartments that have been reached to date 
TABLE 4 | Examples of efficient intracellular delivery of antibodies aimed at various intracellular compartments.

\begin{tabular}{|c|c|c|c|c|c|}
\hline $\begin{array}{l}\text { Intracellular } \\
\text { compartment(s) to } \\
\text { which antibodies or } \\
\text { mimics were } \\
\text { successfully } \\
\text { delivered }\end{array}$ & $\begin{array}{l}\text { Level of action } \\
\text { (in vitro or in vivo) }\end{array}$ & $\begin{array}{l}\text { Type of delivery } \\
\text { (carrier if applicable) }\end{array}$ & Antibody type & Targeted antigen & Reference \\
\hline Cytosol & in vitro & $\begin{array}{l}\text { TAT-HA2 decorated gold } \\
\text { nanoparticles }\end{array}$ & glycosylated mAbs & actin & Kumar et al., 2007, 2008 \\
\hline Cytosol & in vitro & $\begin{array}{l}\text { modular transport systems } \\
\text { including DARPin for cell } \\
\text { specific receptor } \\
\text { recognition and bacterial } \\
\text { toxin-derived component } \\
\text { for endosomal escape and } \\
\text { a different DARPin for } \\
\text { intracellular antigen } \\
\text { recognition }\end{array}$ & $\begin{array}{l}\text { designed ankyrin } \\
\text { repeat protein (DARPin) }\end{array}$ & $\begin{array}{l}\text { mainly none (model cargo } \\
\text { DARPins) }\end{array}$ & Verdurmen et al., 2015 \\
\hline $\begin{array}{l}\text { Endoplasmic reticulum } \\
\text { (ER) }\end{array}$ & in vitro & $\begin{array}{l}\text { intrabody technology: } \\
\text { diethylaminoethyl-dextran } \\
\text { based transfection }\end{array}$ & $\begin{array}{l}\text { scFv fused with } E R \\
\text { retention } K D E L \text { signal }\end{array}$ & $\begin{array}{l}\text { human herpesvirus } 8 \\
\text { interleukin-6 }\end{array}$ & Kovaleva et al., 2006 \\
\hline $\begin{array}{l}\text { Mitochondria, nucleus, } \\
\text { or cytosol }\end{array}$ & $\begin{array}{l}\text { in vitro in cell lines } \\
\text { (all localizations) } \\
\text { and in Xenopus } \\
\text { oocytes } \\
\text { (mitochondria) }\end{array}$ & $\begin{array}{l}\text { intrabody technology: } \\
\text { transient DNA transfection } \\
\text { of cells, mRNA } \\
\text { microinjection to Xenopus } \\
\text { oocytes }\end{array}$ & $\begin{array}{l}\text { scFv fused with nuclear } \\
\text { or mitochondrial } \\
\text { localization signals }\end{array}$ & p21ras, nerve growth factor & Biocca et al., 1995 \\
\hline Nucleus & in vitro & electroporation & mAbs & $\begin{array}{l}\text { proliferating cell nuclear } \\
\text { antigen (PCNA) DNA } \\
\text { polymerase } \alpha, \text { HPV16 E6 } \\
\text { oncogene }\end{array}$ & Freund et al., 2013 \\
\hline Nucleus & in vitro & electroporation & $\begin{array}{l}\text { mAbs and Fabs labeled } \\
\text { with Alexa Fluor } 488\end{array}$ & $\begin{array}{l}\gamma \mathrm{H} 2 \mathrm{AX}, \alpha \text {-tubulin, } \\
\text { heptapeptide repeats of } \\
\text { nonphosphorylated } \\
\text { C-terminal domain of the } \\
\text { largest subunit of RNA Pol } \\
\text { II, TATA binding protein } \\
\text { (TBP), TBP-associated } \\
\text { factor } 10\end{array}$ & Conic et al., 2018 \\
\hline Nucleus & in vitro & $\begin{array}{l}\text { microinjection into either } \\
\text { the nuclei or the cytoplasm }\end{array}$ & $\begin{array}{l}\text { NLS-conjugated } \\
\text { polyclonal antibody } \\
\text { (IgG) }\end{array}$ & $\begin{array}{l}\text { lamin A/C histone-binding } \\
\text { site }\end{array}$ & Dixon et al., 2017 \\
\hline
\end{tabular}

by the delivered antibody; to the best of our knowledge, no approaches for targeting the ER by an externally delivered antibody have yet been published. An efficient cell-specific targeted delivery of antibody for the intracellular antigen of interest from the cell outside requires a stepwise delivery, starting from the specific recognition of the target cells, followed by effective internalization of the construct, with the subsequent endosomal escape to the cytosol and - if necessary further transport to the required cell compartment (e.g., the nucleus or mitochondria). Unfortunately, just a few published delivery strategies integrate all these crucial steps together in one construct. For example, a recent approach for the 
TABLE 5 | Advantages and limitations of different approaches used for the intracellular delivery of antibodies.

\begin{tabular}{|c|c|c|}
\hline Delivery approach & Advantages & Current limitations \\
\hline Direct physical delivery & $\begin{array}{l}\text { delivers antibodies directly inside the cytosol; the ability } \\
\text { to target other compartments upon attachment of the } \\
\text { specific localization signal }\end{array}$ & $\begin{array}{l}\text { usually lacks cell-specificity; rather difficult in vivo and } \\
\text { clinical translation owing to in vivo safety and efficiency } \\
\text { issues }\end{array}$ \\
\hline $\begin{array}{l}\text { Direct intracellular expression (intrabody } \\
\text { approach) }\end{array}$ & $\begin{array}{l}\text { direct expression within the cell; relatively easy direction } \\
\text { of intrabody to the desired cell compartment where the } \\
\text { specific antigen should be bound }\end{array}$ & $\begin{array}{l}\text { rather difficult in vivo and clinical translation owing to } \\
\text { DNA transfection in vivo safety and efficiency issues; } \\
\text { insufficient tissue specificity; delayed onset of the effect; } \\
\text { uncertainties with duration and level of expression; } \\
\text { uncertainty whether the transformation is transient or } \\
\text { permanent }\end{array}$ \\
\hline $\begin{array}{l}\text { Fusion with part of internalizing autoantibodies } \\
\text { responsible for their intrinsic ability to enter cells }\end{array}$ & $\begin{array}{l}\text { relies on intrinsic abilities of autoantibodies to enter the } \\
\text { cell; can be easily re-engineered to obtain more potent } \\
\text { derivatives; can be additionally decorated with tissue } \\
\text { targeting moieties }\end{array}$ & $\begin{array}{l}\text { mechanism of cell entry and endosomal escape not } \\
\text { clearly understood; endosomal escape efficiency issues } \\
\text { lack of tissue and cellular specificity; additional } \\
\text { decoration can hamper antibody reactivity }\end{array}$ \\
\hline $\begin{array}{l}\text { Fusion with protein-transduction domains or } \\
\text { their mimics }\end{array}$ & $\begin{array}{l}\text { can be additionally decorated with tissue targeting and } \\
\text { endosomal escape moieties }\end{array}$ & $\begin{array}{l}\text { questionable efficiency of endosomal escape; generally } \\
\text { lacks tissue and cellular specificity; additional } \\
\text { decoration can hamper antibody reactivity possible } \\
\text { toxicity issues }\end{array}$ \\
\hline Nanocarriers & $\begin{array}{l}\text { generally high loading efficiency; tunable properties of } \\
\text { the carrier, allow rather easy decoration with functional } \\
\text { (e.g., cell-targeting) moieties, which in contrast to direct } \\
\text { antibody modification cannot hamper its reactivity } \\
\text { possible sustained release functionality; possible } \\
\text { adjustments of the pharmacokinetic profile }\end{array}$ & $\begin{array}{l}\text { for the majority of nanocarrier types, the problem of } \\
\text { efficient endosomal escape still needs to be solved; } \\
\text { production can be highly tedious and expensive; } \\
\text { immunogenicity issues due to relatively large size of } \\
\text { nanoparticles }\end{array}$ \\
\hline
\end{tabular}

construction of modular transport systems, including DARPins, for cell specific receptor recognition, bacterial toxin-derived component for endosomal escape, and a different DARPin for intracellular antigen recognition (Verdurmen et al., 2015) was published. This system was demonstrated to deliver DARPins into the cytosol efficiently and cell-specifically. When an antigen of interest is localized within another compartment (e.g., the nucleus or mitochondria), additional signal peptides for specific compartment delivery are required. The delivery system that can serve an appropriate candidate to accomplish this step-by-step targeted cell-specific delivery of antibody (or its derivative/mimic) into the designated intracellular compartment (e.g., the nucleus) is the modular nanotransporters platform (Sobolev, 2009; Sobolev et al., 2016). Modular nanotransporters are recombinant polypeptide-based delivery vehicles, consisting of a ligand module for cell-specific recognition and subsequent internalization, the translocation domain of Diphtheria toxin as an endosomolytic module for successful endosomal escape, and the optimized SV-40 large T-antigen nuclear localization sequence for nuclear import. The feasibility of this platform has already been demonstrated in vitro and in vivo for the delivery of locally acting anti-cancer drugs, such as photosensitizers (Slastnikova et al., 2012b,c), several types of radionuclides [ $\alpha$-emitters (Rosenkranz et al., 2008), and Auger electron emitters (Slastnikova et al., 2012a, 2017b; Koumarianou et al., 2014)] into various types of cancer cells. The cancer cell specificity was easily modulated by the choice of appropriate ligand module [e.g., epidermal growth factor (Gilyazova et al., 2006), $\alpha$-melanocyte stimulating hormone (Rosenkranz et al., 2003), and folic acid (Rosenkranz et al., 2017; Slastnikova et al., 2017a)] for the characteristic internalizable receptor overexpressed on the target cells. Recently, the principal feasibility of the construction of modular nanotransporters bearing anti-cMyc scFv (as an example) was demonstrated (Ulasov et al., 2018), which may be a promising new step toward the efficient targeted delivery of antibodies inside the target cells.

\section{Directed Subcellular Relocation of Target Molecules}

Another theme that emerges from the intracellular antibody delivery concept is the ability to relocate protein-of-interest within the cells or deplete it through a cellular protein elimination system. Protein relocation is an approach to interfere with target protein function through trapping it with binder molecule and thereby preventing the target protein transport to a defined cellular compartment. The feasibility of such strategy was demonstrated with intracellular antibodies, which inhibited heterochromatin protein $1 \beta$ traffic to the nucleus (Cardinale et al., 2015), resulting in altered nuclear morphology and apoptosis. Another group reported intracellular antibody binding to Sec61 and prevention of its transport from the ER toward endosomes (Zehner et al., 2015). To interfere with the target protein function, the intracellular antibody must be: (1) delivered into cells at a stoichiometric concentration; (2) bound to the target in a way that blocks its function, and (3) ensured for high affinity binding, otherwise the equilibrium will shift toward target escape from antibody complex before reaching desirable effect. These are strict conditions that limit the possible applications of intracellular antibodies against relatively low-abundant targets and/or molecules with a very high affinity toward the target.

Notwithstanding the elimination of the target, once bound to the antibody, it could circumvent this equilibrium conundrum. 
For specific degradation of proteins, cells contain proteasome systems, which are highly efficient and elaborate machinery for the regulation of protein turnover and protection from misfolded and damaged proteins (Bhattacharyya et al., 2014). A ubiquitin-dependent system is the major pathway for specific protein degradation, for which protein ubiquitination is a prerequisite step (Hershko and Ciechanover, 1998). Ubiquitination is a multistep enzymatic process, that involves three types of enzyme: E1 ubiquitin activating enzyme; E2 ubiquitin conjugating enzyme; and E3 ubiquitin protein ligase (Komander and Rape, 2012). The substrate specificity is conferred by hundreds of E3 ubiquitin ligases (Senft et al., 2018), belonging to HECT, RING, and U-box families, according to their mode of action. RING and U-box E3 ubiquitin ligases function as scaffolds for E2 ubiquitin conjugating enzymes, whereas HECT proteins form a thiol-ester bond with ubiquitin before transferring it to the substrates (Pickart, 2001). Harnessing an endogenous protein control system is a viable approach to downregulate the target proteins (Schrader et al., 2009). For this purpose, the binder moiety should be fused with a module targeting the protein to the proteasomes. Several examples of such reprogrammed E3 ubiquitin ligases have been described, based on multisubunit RING E3 enzymes, targeting $\beta$-catenin ( $\mathrm{Su}$ et al., 2003; Liu et al., 2004) or mono-molecule U-box protein CHIP E3 ligase, degrading KRAS (Ma et al., 2013; Pan et al., 2016), c-Myc (Hatakeyama et al., 2005), epidermal growth factor receptor mutants (Chung et al., 2016). Fusion with CHIP has several advantages over RING E3 ligases, such as broad substrate diversity and a lack of dependence on other subunits (Portnoff et al., 2014). By virtue of the catalytic nature of the ubiquitin system, enabling multiple rounds of activity, depletion of abundant targets, even exceeding the amount of delivered antibody may be possible.

\section{REFERENCES}

Abraham, A., Natraj, U., Karande, A. A., Gulati, A., Murthy, M. R., Murugesan, S., et al. (2016). Intracellular delivery of antibodies by chimeric Sesbania mosaic virus (SeMV) virus like particles. Sci. Rep. 6:21803. doi: 10.1038/srep21803

Adams, G. P., and Weiner, L. M. (2005). Monoclonal antibody therapy of cancer. Nat. Biotechnol. 23, 1147-1157. doi: 10.1038/nbt1137

Aihara, H., and Miyazaki, J. (1998). Gene transfer into muscle by electroporation in vivo. Nat. Biotechnol. 16, 867-870. doi: 10.1038/nbt0998-867

Akishiba, M., Takeuchi, T., Kawaguchi, Y., Sakamoto, K., Yu, H. H., Nakase, I., et al. (2017). Cytosolic antibody delivery by lipid-sensitive endosomolytic peptide. Nat. Chem. 9, 751-761. doi: 10.1038/nchem.2779

Alarcon-Segovia, D., Llorente, L., and Ruiz-Arguelles, A. (1996). The penetration of autoantibodies into cells may induce tolerance to self by apoptosis of autoreactive lymphocytes and cause autoimmune disease by dysregulation and/or cell damage. J. Autoimmun. 9, 295-300. doi: 10.1006/jaut.1996.0038

Alarcon-Segovia, D., Ruiz-Arguelles, A., and Llorente, L. (1979). Antibody penetration into living cells. II. Anti-ribonucleoprotein IgG penetrates into Tgamma lymphocytes causing their deletion and the abrogation of suppressor function. J. Immunol. 122, 1855-1862.

Ali, S. A., Teow, S. Y., Omar, T. C., Khoo, A. S., Choon, T. S., and Yusoff, N. M. (2016). A cell internalizing antibody targeting capsid protein (p24) inhibits the replication of HIV-1 in T cells lines and PBMCs: a proof of concept study. PLoS One 11:e0145986. doi: 10.1371/journal.pone.0145986

\section{CONCLUSION}

Three decades of progress in strategies for efficient targeted intracellular delivery of antibodies has led to the development of various approaches, from direct physical methods and gene delivery to sophisticated synthetic delivery vehicles. Although widely utilized for intracellular protein function studies, the therapeutic applications of this promising precise approach remains in the in vitro stages and rarely progresses to in vivo studies; thus, there is much room for improvement. We hope that both the elucidation of normal behavior of antibodies within cells, including their relocation and degradation pathways, as well as the development of specific, effective, and clinically applicable systems of targeted intracellular protein delivery will allow this approach to be used as a clinical therapy in future.

\section{AUTHOR CONTRIBUTIONS}

TS, AU analyzed the literature, wrote the article, and designed the figures and tables in the article. AR and AS analyzed the literature, wrote the article, and critically reviewed the article.

\section{FUNDING}

This work was supported by the Russian Science Foundation Grant 17-14-01304.

\section{ACKNOWLEDGMENTS}

We thank Richard H. Lozier for his interest in this work and for language editing.

Alirahimi, E., Ashkiyan, A., Kazemi-Lomedasht, F., Azadmanesh, K., Hosseininejad-Chafi, M., Habibi-Anbouhi, M., et al. (2017). Intrabody targeting vascular endothelial growth factor receptor-2 mediates downregulation of surface localization. Cancer Gene Ther. 24, 33-37. doi: 10.1038/cgt.2016.76

Aluri, R., and Jayakannan, M. (2017). Development of l-tyrosine-based enzymeresponsive amphiphilic poly(ester-urethane) nanocarriers for multiple drug delivery to cancer cells. Biomacromolecules 18, 189-200. doi: 10.1021/acs. biomac.6b01476

Alvarez, R. D., Barnes, M. N., Gomez-Navarro, J., Wang, M., Strong, T. V., Arafat, W., et al. (2000). A cancer gene therapy approach utilizing an antierbB-2 single-chain antibody-encoding adenovirus (AD21): a phase I trial. Clin. Cancer Res. 6, 3081-3087.

Alzogaray, V., Danquah, W., Aguirre, A., Urrutia, M., Berguer, P., Garcia, V. E., et al. (2011). Single-domain llama antibodies as specific intracellular inhibitors of SpvB, the actin ADP-ribosylating toxin of Salmonella typhimurium. FASEB J. 25, 526-534. doi: 10.1096/fj.10-162958

Amici, C., Visintin, M., Verachi, F., Paolini, F., Percario, Z., Di, B. P., et al. (2016). A novel intracellular antibody against the E6 oncoprotein impairs growth of human papillomavirus 16-positive tumor cells in mouse models. Oncotarget. 7, 15539-15553. doi: 10.18632/oncotarget.6925

Amornwachirabodee, K., Tantimekin, N., Pan-In, P., Palaga, T., Pienpinijtham, P., Pipattanaboon, C., et al. (2018). Oxidized Carbon Black: Preparation, Characterization and Application in Antibody Delivery across Cell Membrane. Sci. Rep. 8:2489 doi: 10.1038/s41598-018-20650-4 
Anderson, D. C., Nichols, E., Manger, R., Woodle, D., Barry, M., and Fritzberg, A. R. (1993). Tumor cell retention of antibody Fab fragments is enhanced by an attached HIV TAT protein-derived peptide. Biochem. Biophys. Res. Commun. 194, 876-884. doi: 10.1006/bbrc.1993.1903

Ashour, J., Schmidt, F. I., Hanke, L., Cragnolini, J., Cavallari, M., Altenburg, A., et al. (2015). Intracellular expression of camelid single-domain antibodies specific for influenza virus nucleoprotein uncovers distinct features of its nuclear localization. J. Virol. 89, 2792-2800. doi: 10.1128/JVI.02693-14

Avignolo, C., Bagnasco, L., Biasotti, B., Melchiori, A., Tomati, V., Bauer, I., et al. (2008). Internalization via Antennapedia protein transduction domain of an scFv antibody toward c-Myc protein. FASEB J. 22, 1237-1245. doi: 10.1096/fj. 07-8865com

Bach, H., Mazor, Y., Shaky, S., Shoham-Lev, A., Berdichevsky, Y., Gutnick, D. L., et al. (2001). Escherichia coli maltose-binding protein as a molecular chaperone for recombinant intracellular cytoplasmic single-chain antibodies. J. Mol. Biol. 312, 79-93. doi: 10.1006/jmbi.2001.4914

Baron, S., Poast, J., Rizzo, D., McFarland, E., and Kieff, E. (2000). Electroporation of antibodies, DNA, and other macromolecules into cells: a highly efficient method. J. Immunol. Methods 242, 115-126. doi: 10.1016/S0022-1759(00) 00242-8

Beck, A., Wurch, T., Bailly, C., and Corvaia, N. (2010). Strategies and challenges for the next generation of therapeutic antibodies. Nat. Rev. Immunol. 10, 345-352. doi: $10.1038 /$ nri2747

Benavent Acero, F. R., Perera, N. Y., Alonso, D. F., Perea, S. E., Gomez, D. E., and Farina, H. G. (2014). Mechanisms of cellular uptake, intracellular transportation, and degradation of CIGB-300, a Tat-conjugated peptide, in tumor cell lines. Mol. Pharm. 11, 1798-1807. doi: 10.1021/mp4006062

Bhattacharyya, S., Yu, H., Mim, C., and Matouschek, A. (2014). Regulated protein turnover: snapshots of the proteasome in action. Nat. Rev. Mol. Cell Biol. 15, 122-133. doi: 10.1038/nrm3741

Binz, H. K., Amstutz, P., and Pluckthun, A. (2005). Engineering novel binding proteins from nonimmunoglobulin domains. Nat. Biotechnol. 23, 1257-1268. doi: $10.1038 /$ nbt1127

Biocca, S., Di, L. A., Werge, T., and Cattaneo, A. (1991). Intracellular immunization: Expression of antibody domains in the cytoplasm and in the nucleus of mammalian cells. Cytotechnology 5, 49-50. doi: 10.1007/BF00736806

Biocca, S., Ruberti, F., Tafani, M., Pierandrei-Amaldi, P., and Cattaneo, A. (1995). Redox state of single chain Fv fragments targeted to the endoplasmic reticulum, cytosol and mitochondria. Biotechnology 13, 1110-1115. doi: 10.1038/nbt10951110

Boldicke, T. (2017). Single domain antibodies for the knockdown of cytosolic and nuclear proteins. Protein Sci. 26, 925-945. doi: 10.1002/pro.3154

Bolhassani, A., Jafarzade, B. S., and Mardani, G. (2017). In vitro and in vivo delivery of therapeutic proteins using cell penetrating peptides. Peptides 87, 50-63. doi: 10.1016/j.peptides.2016.11.011

Boons, E., Li, G., Vanstreels, E., Vercruysse, T., Pannecouque, C., Vandamme, A. M., et al. (2014). A stably expressed llama single-domain intrabody targeting Rev displays broad-spectrum anti-HIV activity. Antiviral Res. 112, 91-102. doi: 10.1016/j.antiviral.2014.10.007

Borrelli, A., Tornesello, A. L., Tornesello, M. L., and Buonaguro, F. M. (2018). Cell Penetrating peptides as molecular carriers for anti-cancer agents. Molecules 23:E295. doi: 10.3390/molecules23020295

Braunova, A., Kostka, L., Sivak, L., Cuchalova, L., Hvezdova, Z., Laga, R., et al. (2017). Tumor-targeted micelle-forming block copolymers for overcoming of multidrug resistance. J. Control Release 245, 41-51. doi: 10.1016/j.jconrel.2016. 11.020

Brown, J. R., Cymbalista, F., Sharman, J., Jacobs, I., Nava-Parada, P., and Mato, A. (2017). The Role of Rituximab in Chronic Lymphocytic Leukemia Treatment and the Potential Utility of Biosimilars. Oncologist 23, 288-296. doi: 10.1634/ theoncologist.2017-0150

Bruce, V. J., Lopez-Islas, M., and McNaughton, B. R. (2016). Resurfaced cellpenetrating nanobodies: A potentially general scaffold for intracellularly targeted protein discovery. Protein Sci. 25, 1129-1137. doi: 10.1002/pro. 2926

Buning, H. (2013). Gene therapy enters the pharma market: the short story of a long journey. EMBO Mol. Med. 5, 1-3. doi: 10.1002/emmm.201202291
Butler, D. C., and Messer, A. (2011). Bifunctional anti-huntingtin proteasomedirected intrabodies mediate efficient degradation of mutant huntingtin exon 1 protein fragments. PLoS One 6:e29199. doi: 10.1371/journal.pone.0029199

Canton, I., Massignani, M., Patikarnmonthon, N., Chierico, L., Robertson, J., Renshaw, S. A., et al. (2013). Fully synthetic polymer vesicles for intracellular delivery of antibodies in live cells. FASEB J. 27, 98-108. doi: 10.1096/fj.12212183

Cardinale, A., Filesi, I., Singh, P. B., and Biocca, S. (2015). Intrabody-mediated diverting of HP1beta to the cytoplasm induces co-aggregation of $\mathrm{H} 3-\mathrm{H} 4$ histones and lamin-B receptor. Exp. Cell Res. 338, 70-81. doi: 10.1016/j.yexcr. 2015.09.006

Carlson, J. R. (1988). A new means of inducibly inactivating a cellular protein. Mol. Cell Biol. 8, 2638-2646. doi: 10.1128/MCB.8.6.2638

Carter, P. J., and Lazar, G. A. (2018). Next generation antibody drugs: pursuit of the 'high-hanging fruit'. Nat. Rev. Drug Discov. 17, 197-223. doi: 10.1038/nrd. 2017.227

Cetin, M., Evenson, W. E., Gross, G. G., Jalali-Yazdi, F., Krieger, D., Arnold, D., et al. (2017). RasIns: genetically encoded intrabodies of activated ras proteins. J. Mol. Biol. 429, 562-573. doi: 10.1016/j.jmb.2016.11.008

Chakrabarti, R., Wylie, D. E., and Schuster, S. M. (1989). Transfer of monoclonal antibodies into mammalian cells by electroporation. J. Biol. Chem. 264, 15494-15500.

Chan, G., Jordaan, G., Nishimura, R. N., and Weisbart, R. H. (2016). Combining intracellular antibodies to restore function of mutated p53 in cancer. Int. J. Cancer 138, 182-186. doi: 10.1002/ijc.29685

Chatin, B., Mevel, M., Devalliere, J., Dallet, L., Haudebourg, T., Peuziat, P., et al. (2015). Liposome-based formulation for intracellular delivery of functional proteins. Mol. Ther. Nucleic Acids 4:e244. doi: 10.1038/mtna.2015.17

Chen, B. X., and Erlanger, B. F. (2002). Intracellular delivery of monoclonal antibodies. Immunol. Lett. 84, 63-67. doi: 10.1016/S0165-2478(02)00146-3

Chen, B. X., and Erlanger, B. F. (2006). Cell cycle inhibition by an anti-cyclin D1 antibody chemically modified for intracellular delivery. Cancer Lett. 244, 71-75. doi: 10.1016/j.canlet.2005.12.011

Chen, Z., Patel, J. M., Noble, P. W., Garcia, C., Hong, Z., and Hansen, J. E. et al. (2016). A lupus anti-DNA autoantibody mediates autocatalytic, targeted delivery of nanoparticles to tumors. Oncotarget 7, 59965-59975. doi: 10.18632/ oncotarget.11015

Chirichella, M., Lisi, S., Fantini, M., Goracci, M., Calvello, M., Brandi, R., et al. (2017). Post-translational selective intracellular silencing of acetylated proteins with de novo selected intrabodies. Nat. Methods 14, 279-282. doi: 10.1038/ nmeth.4144

Chiu, H. Y., Deng, W., Engelke, H., Helma, J., Leonhardt, H., and Bein, T. (2016). Intracellular chromobody delivery by mesoporous silica nanoparticles for antigen targeting and visualization in real time. Sci. Rep. 6:25019 doi: 10 . 1038/srep25019

Choi, D. K., Bae, J., Shin, S. M., Shin, J. Y., Kim, S., and Kim, Y. S. (2014). A general strategy for generating intact, full-length IgG antibodies that penetrate into the cytosol of living cells. MAbs 6, 1402-1414. doi: 10.4161/mabs.36389

Chung, C., Yoo, G., Kim, T., Lee, D., Lee, C. S., and Cha, H. R. et al. (2016). The E3 ubiquitin ligase CHIP selectively regulates mutant epidermal growth factor receptor by ubiquitination and degradation. Biochem. Biophys. Res. Commun. 479, 152-158. doi: 10.1016/j.bbrc.2016.07.111

Clift, D., McEwan, W. A., Labzin, L. I., Konieczny, V., Mogessie, B., and James, L. C. et al. (2017). A method for the acute and rapid degradation of endogenous proteins. Cell 171, 1692-1706. doi: 10.1016/j.cell.2017.10.033

Cohen-Saidon, C., Nechushtan, H., Kahlon, S., Livni, N., Nissim, A., and Razin, E. (2003). A novel strategy using single-chain antibody to show the importance of Bcl-2 in mast cell survival. Blood 102, 2506-2512. doi: 10.1182/blood-2002-123921

Colby, D. W., Chu, Y., Cassady, J. P., Duennwald, M., Zazulak, H., Webster, J. M., et al. (2004). Potent inhibition of huntingtin aggregation and cytotoxicity by a disulfide bond-free single-domain intracellular antibody. Proc. Natl. Acad. Sci. U.S.A. 101, 17616-17621. doi: 10.1073/pnas.0408134101

Coleman, M., Lammers, P. E., Ciceri, F., and Jacobs, I. A. (2016). Role of Rituximab and Rituximab biosimilars in diffuse large B-cell lymphoma. Clin. Lymphoma Myeloma. Leuk. 16, 175-181. doi: 10.1016/j.clml.2016.01.004 
Colwill, K., and Graslund, S. (2011). A roadmap to generate renewable protein binders to the human proteome. Nat. Methods 8, 551-558. doi: 10.1038/nmeth. 1607

Conic, S., Desplancq, D., Ferrand, A., Fischer, V., Heyer, V., Reina San, M. B., et al. (2018). Imaging of native transcription factors and histone phosphorylation at high resolution in live cells. J. Cell Biol. 217, 1537-1552. doi: 10.1083/jcb. 201709153

Courtete, J., Sibler, A. P., Zeder-Lutz, G., Dalkara, D., Oulad-Abdelghani, M., Zuber, G., et al. (2007). Suppression of cervical carcinoma cell growth by intracytoplasmic codelivery of anti-oncoprotein E6 antibody and small interfering RNA. Mol. Cancer Ther. 6, 1728-1735. doi: 10.1158/1535-7163. MCT-06-0808

Cox, A. D., Fesik, S. W., Kimmelman, A. C., Luo, J., and Der, C. J. (2014). Drugging the undruggable RAS: mission possible? Nat. Rev. Drug Discov. 13, 828-851. doi: $10.1038 / \mathrm{nrd} 4389$

Crews, C. M. (2010). Targeting the undruggable proteome: the small molecules of my dreams. Chem. Biol. 17, 551-555. doi: 10.1016/j.chembiol.2010.05.011

Dalkara, D., Zuber, G., and Behr, J. P. (2004). Intracytoplasmic delivery of anionic proteins. Mol. Ther. 9, 964-969. doi: 10.1016/j.ymthe.2004.03.007

Dang, C. V., Reddy, E. P., Shokat, K. M., and Soucek, L. (2017). Drugging the 'undruggable' cancer targets. Nat. Rev. Cancer 17, 502-508. doi: 10.1038/nrc. 2017.36

Daud, A. I., DeConti, R. C., Andrews, S., Urbas, P., Riker, A. I., Sondak, V. K., et al. (2008). Phase I trial of interleukin-12 plasmid electroporation in patients with metastatic melanoma. J. Clin. Oncol. 26, 5896-5903. doi: 10.1200/JCO.2007.15. 6794

de la Torre, B. G., and Albericio, F. (2018). The Pharmaceutical Industry in 2017. An analysis of FDA drug approvals from the perspective of molecules. Molecules 23:E533 doi: 10.3390/molecules23030533

Del Bano, J., Chames, P., Baty, D., and Kerfelec, B. (2015). Taking up cancer immunotherapy challenges: bispecific antibodies, the path forward? Antibodies 5:1 doi: 10.3390/antib5010001

Deshane, J., Siegal, G. P., Alvarez, R. D., Wang, M. H., Feng, M., Cabrera, G., et al. (1995). Targeted tumor killing via an intracellular antibody against erbB-2. J. Clin. Invest. 96, 2980-2989. doi: 10.1172/JCI118370

Desplancq, D., Freund, G., Conic, S., Sibler, A. P., Didier, P., Stoessel, A., et al. (2016). Targeting the replisome with transduced monoclonal antibodies triggers lethal DNA replication stress in cancer cells. Exp. Cell Res. 342, 145-158. doi: 10.1016/j.yexcr.2016.03.003

Discher, B. M., Won, Y. Y., Ege, D. S., Lee, J. C., Bates, F. S., Discher, D. E., et al. (1999). Polymersomes: tough vesicles made from diblock copolymers. Science 284, 1143-1146. doi: 10.1126/science.284.5417.1143

Dixon, C. R., Platani, M., Makarov, A. A., and Schirmer, E. C. (2017). Microinjection of Antibodies Targeting the Lamin A/C Histone-Binding Site Blocks Mitotic Entry and Reveals Separate Chromatin Interactions with HP1, CenpB and PML. Cells 6:E9 doi: 10.3390/cells6020009

Dixon, J. E., Osman, G., Morris, G. E., Markides, H., Rotherham, M., Bayoussef, Z., et al. (2016). Highly efficient delivery of functional cargoes by the synergistic effect of GAG binding motifs and cell-penetrating peptides. Proc. Natl. Acad. Sci. U.S.A. 113, E291-E299. doi: 10.1073/pnas.1518634113

Donini, M., Morea, V., Desiderio, A., Pashkoulov, D., Villani, M. E., Tramontano, A., et al. (2003). Engineering stable cytoplasmic intrabodies with designed specificity. J. Mol. Biol. 330, 323-332. doi: 10.1016/S0022-2836(03) 00530-8

Douglas, J. N. G. L., Gardner, L. A., and Levin, M. C. (2013). Antibodies to an intracellular antigen penetrate neuronal cells and cause deleterious effects. J. Clin. Cell Immunol. 4:134. doi: 10.4172/2155-9899.1000134

Durymanov, M. O., Slastnikova, T. A., Kuzmich, A. I., Khramtsov, Y. V., Ulasov, A. V., Rosenkranz, A. A., et al. (2013). Microdistribution of MC1R-targeted polyplexes in murine melanoma tumor tissue. Biomaterials 34, 10209-10216. doi: 10.1016/j.biomaterials.2013.08.076

Elgundi, Z., Reslan, M., Cruz, E., Sifniotis, V., and Kayser, V. (2017). The stateof-play and future of antibody therapeutics. Adv. Drug Deliv. Rev. 122, 2-19. doi: 10.1016/j.addr.2016.11.004

El-Sayed, A., Futaki, S., and Harashima, H. (2009). Delivery of macromolecules using arginine-rich cell-penetrating peptides: ways to overcome endosomal entrapment. AAPS J. 11, 13-22. doi: 10.1208/s12248-0089071-2
Fathi, M., Sahandi, Z. P., Barar, J., Aghanejad, A., Erfan-Niya, H., and Omidi, Y. (2018). Thermo-sensitive chitosan copolymer-gold hybrid nanoparticles as a nanocarrier for delivery of erlotinib. Int. J. Biol. Macromol. 106, 266-276. doi: 10.1016/j.ijbiomac.2017.08.020

Fischer, R., Bachle, D., Fotin-Mleczek, M., Jung, G., Kalbacher, H., and Brock, R. (2006). A targeted protease substrate for a quantitative determination of protease activities in the endolysosomal pathway. Chembiochem 7, 1428-1434. doi: 10.1002/cbic.200600209

Frankel, A. D., and Pabo, C. O. (1988). Cellular uptake of the tat protein from human immunodeficiency virus. Cell 55, 1189-1193. doi: 10.1016/00928674(88)90263-2

Frenzel, A., Kugler, J., Helmsing, S., Meier, D., Schirrmann, T., Hust, M., et al. (2017). Designing human antibodies by phage display. Transfus. Med. Hemother. 44, 312-318. doi: 10.1159/000479633

Freund, G., Sibler, A. P., Desplancq, D., Oulad-Abdelghani, M., Vigneron, M., Gannon, J., et al. (2013). Targeting endogenous nuclear antigens by electrotransfer of monoclonal antibodies in living cells. MAbs 5, 518-522. doi: $10.4161 /$ mabs. 25084

Gao, L., Han, L., Ding, X., Xu, J., Wang, J., Zhu, J., et al. (2017). An effective intracellular delivery system of monoclonal antibody for treatment of tumors: erythrocyte membrane-coated self-associated antibody nanoparticles. Nanotechnology 28:335101 doi: 10.1088/1361-6528/aa7c43

Gebauer, M., and Skerra, A. (2015). "Alternative protein scaffolds as novel biotherapeutics," in Biobetters. AAPS Advances in the Pharmaceutical Sciences Series, eds A. Rosenberg and B. Demeule (New York, NY: Springer), 221-268. doi: 10.1007/978-1-4939-2543-8_13

Ghetie, V., and Ward, E. S. (2002). Transcytosis and catabolism of antibody. Immunol. Res. 25, 97-113. doi: 10.1385/IR:25:2:097

Gilyazova, D. G., Rosenkranz, A. A., Gulak, P. V., Lunin, V. G., Sergienko, O. V., Khramtsov, Y. V., et al. (2006). Targeting cancer cells by novel engineered modular transporters. Cancer Res. 66, 10534-10540. doi: 10.1158/0008-5472. CAN-06-2393

Gire, V., and Wynford-Thomas, D. (1998). Reinitiation of DNA synthesis and cell division in senescent human fibroblasts by microinjection of anti-p53 antibodies. Mol. Cell Biol. 18, 1611-1621. doi: 10.1128/MCB.18.3.1611

Glab-Ampai, K., Chulanetra, M., Malik, A. A., Juntadech, T., Thanongsaksrikul, J., Srimanote, P., et al. (2017). Human single chain-transbodies that bound to domain-I of non-structural protein 5A (NS5A) of hepatitis C virus. Sci. Rep. 7:15042. doi: 10.1038/s41598-017-14886-9

Godar, M., de, H. H., Blanchetot, C., and Rasser, J. (2018). Therapeutic bispecific antibody formats: a patent applications review (1994-2017). Expert Opin. Ther. Pat. 28, 251-276. doi: 10.1080/13543776.2018.1428307

Green, M., and Loewenstein, P. M. (1988). Autonomous functional domains of chemically synthesized human immunodeficiency virus tat trans-activator protein. Cell 55, 1179-1188. doi: 10.1016/0092-8674(88)90262-0

Guglielmi, L., Denis, V., Vezzio-Vie, N., Bec, N., Dariavach, P., Larroque, C., et al. (2011). Selection for intrabody solubility in mammalian cells using GFP fusions. Protein Eng. Des. Sel. 24, 873-881. doi: 10.1093/protein/gzr049

Hamers-Casterman, C., Atarhouch, T., Muyldermans, S., Robinson, G., Hamers, C., Songa, E. B., et al. (1993). Naturally occurring antibodies devoid of light chains. Nature 363, 446-448. doi: 10.1038/363446a0

Hammond, C., and Helenius, A. (1994). Quality control in the secretory pathway: retention of a misfolded viral membrane glycoprotein involves cycling between the ER, intermediate compartment, and Golgi apparatus. J. Cell Biol. 126, 41-52. doi: $10.1083 /$ jcb.126.1.41

Hansen, J. E., Chan, G., Liu, Y., Hegan, D. C., Dalal, S., Dray, E., et al. (2012). Targeting cancer with a lupus autoantibody. Sci. Transl. Med. 4:157ra142. doi: 10.1126/scitranslmed.3004385

Hansen, J. E., Sohn, W., Kim, C., Chang, S. S., Huang, N. C., and Santos, D. G. et al. (2006). Antibody-mediated Hsp70 protein therapy. Brain Res. 1088, 187-196. doi: 10.1016/j.brainres.2006.03.025

Hansen, J. E., Tse, C. M., Chan, G., Heinze, E. R., Nishimura, R. N., and Weisbart, R. H. (2007). Intranuclear protein transduction through a nucleoside salvage pathway. J. Biol. Chem. 282, 20790-20793. doi: 10.1074/jbc.C700090200

Hatakeyama, S., Watanabe, M., Fujii, Y., and Nakayama, K. I. (2005). Targeted destruction of c-Myc by an engineered ubiquitin ligase suppresses cell transformation and tumor formation. Cancer Res. 65, 7874-7879. doi: 10.1158/ 0008-5472.CAN-05-1581 
Heller, L. C., and Heller, R. (2010). Electroporation gene therapy preclinical and clinical trials for melanoma. Curr. Gene Ther. 10, 312-317. doi: 10.2174/ 156652310791823489

Herce, H. D., Schumacher, D., Schneider, A. F. L., Ludwig, A. K., Mann, F. A., Fillies, M., et al. (2017). Cell-permeable nanobodies for targeted immunolabelling and antigen manipulation in living cells. Nat. Chem. 9, 762-771. doi: 10.1038/nchem.2811

Hershko, A., and Ciechanover, A. (1998). The ubiquitin system. Annu. Rev. Biochem. 67, 425-479. doi: 10.1146/annurev.biochem.67.1.425

Higueruelo, A. P., Jubb, H., and Blundell, T. L. (2013). Protein-protein interactions as druggable targets: recent technological advances. Curr. Opin. Pharmacol. 13, 791-796. doi: 10.1016/j.coph.2013.05.009

Hu, M., Chen, P., Wang, J., Scollard, D. A., Vallis, K. A., and Reilly, R. M. (2007). 123I-labeled HIV-1 tat peptide radioimmunoconjugates are imported into the nucleus of human breast cancer cells and functionally interact in vitro and in vivo with the cyclin-dependent kinase inhibitor, p21(WAF-1/Cip-1). Eur. J. Nucl. Med. Mol. Imaging 34, 368-377. doi: 10.1007/s00259-006-0189-0

Hudis, C. A. (2007). Trastuzumab-mechanism of action and use in clinical practice. N. Engl. J. Med. 357, 39-51. doi: 10.1056/NEJMra043186

Itakura, S., Hama, S., Ikeda, H., Mitsuhashi, N., Majima, E., and Kogure, K. (2015). Effective capture of proteins inside living cells by antibodies indirectly linked to a novel cell-penetrating polymer-modified protein A derivative. FEBS J. 282, 142-152. doi: $10.1111 /$ febs.13111

Jang, J. Y., Jeong, J. G., Jun, H. R., Lee, S. C., Kim, J. S., Kim, Y. S., et al. (2009). A nucleic acid-hydrolyzing antibody penetrates into cells via caveolae-mediated endocytosis, localizes in the cytosol and exhibits cytotoxicity. Cell Mol. Life Sci. 66, 1985-1997. doi: 10.1007/s00018-009-9179-2

Jittavisutthikul, S., Seesuay, W., Thanongsaksrikul, J., Thueng-In, K., Srimanote, P., Werner, R. G., et al. (2016). Human transbodies to HCV NS3/4A protease inhibit viral replication and restore host innate immunity. Front. Immunol. 7:318. doi: 10.3389/fimmu.2016.00318

Joshi, S. N., Butler, D. C., and Messer, A. (2012). Fusion to a highly charged proteasomal retargeting sequence increases soluble cytoplasmic expression and efficacy of diverse anti-synuclein intrabodies. MAbs 4, 686-693. doi: 10.4161/ mabs. 21696

Jurado, P., de Lorenzo, V., and Fernandez, L. A. (2006). Thioredoxin fusions increase folding of single chain Fv antibodies in the cytoplasm of Escherichia coli: evidence that chaperone activity is the prime effect of thioredoxin. J. Mol. Biol. 357, 49-61. doi: 10.1016/j.jmb.2005.12.058

Kang, H. J., Choe, W., Kim, B. M., and Chung, S. J. (2015). IgG Fc-binding peptide (FCBP)-tat conjugate as a smart antibody carrier into live cells. Macromol. Res. 23, 876-881. doi: 10.1007/s13233-015-3118-x

Kashyap, S., Singh, N., Surnar, B., and Jayakannan, M. (2016). Enzyme and thermal dual responsive amphiphilic polymer core-shell nanoparticle for doxorubicin delivery to cancer cells. Biomacromolecules 17, 384-398. doi: 10.1021/acs. biomac.5b01545

Keppeke, G. D., Andrade, L. E., Grieshaber, S. S., and Chan, E. K. (2015). Microinjection of specific anti-IMPDH2 antibodies induces disassembly of cytoplasmic rods/rings that are primarily stationary and stable structures. Cell Biosci. 5:1. doi: 10.1186/2045-3701-5-1

Kim, A., Miura, Y., Ishii, T., Mutaf, O. F., Nishiyama, N., Cabral, H., et al. (2016). Intracellular delivery of charge-converted monoclonal antibodies by combinatorial design of block/homo polyion complex micelles. Biomacromolecules 17, 446-453. doi: 10.1021/acs.biomac.5b01335

Kim, H., Chung, K., Lee, S., Kim, D. H., and Lee, H. (2016). Near-infrared light-responsive nanomaterials for cancer theranostics. Wiley Interdiscip. Rev. Nanomed. Nanobiotechnol. 8, 23-45. doi: 10.1002/wnan.1347

Kim, J. S., Choi, D. K., Shin, J. Y., Shin, S. M., Park, S. W., Cho, H. S., et al. (2016). Endosomal acidic $\mathrm{pH}$-induced conformational changes of a cytosol-penetrating antibody mediate endosomal escape. J. Control. Release 235, 165-175. doi: 10.1016/j.jconrel.2016.05.066

Kim, J. S., Choi, D. K., Park, S. W., Shin, S. M., Bae, J., and Kim, D. M. et al. (2015). Quantitative assessment of cellular uptake and cytosolic access of antibody in living cells by an enhanced split GFP complementation assay. Biochem. Biophys. Res. Commun. 467, 771-777. doi: 10.1016/j.bbrc.2015. 10.066

Kim, Y. M., Park, S. C., and Jang, M. K. (2017). Targeted gene delivery of polyethyleneimine-grafted chitosan with RGD dendrimer peptide in alphavbeta3 integrin-overexpressing tumor cells. Carbohydr. Polym. 174, 1059-1068. doi: 10.1016/j.carbpol.2017.07.035

Klepsch, V., Hermann-Kleiter, N., Do-Dinh, P., Jakic, B., Offermann, A., Efremova, M., et al. (2018). Nuclear receptor NR2F6 inhibition potentiates responses to PD-L1/PD-1 cancer immune checkpoint blockade. Nat. Commun. 9:1538 doi: 10.1038/s41467-018-04004-2

Komander, D., and Rape, M. (2012). The ubiquitin code. Annu. Rev. Biochem. 81, 203-229. doi: 10.1146/annurev-biochem-060310-170328

Kondo, Y., Fushikida, K., Fujieda, T., Sakai, K., Miyata, K., Kato, F., et al. (2008). Efficient delivery of antibody into living cells using a novel HVJ envelope vector system. J. Immunol. Methods 332, 10-17. doi: 10.1016/j.jim.2007. 12.008

Koo, M. Y., Park, J., Lim, J. M., Joo, S. Y., Shin, S. P., Shim, H. B., et al. (2014). Selective inhibition of the function of tyrosine-phosphorylated STAT3 with a phosphorylation site-specific intrabody. Proc. Natl. Acad. Sci. U.S.A. 111, 6269-6274. doi: 10.1073/pnas.1316815111

Kotlyar, M., Rossos, A. E. M., and Jurisica, I. (2017). Prediction of Protein-Protein Interactions. Curr. Protoc. Bioinformatics 60, 8.2.1-8.2.14.

Koumarianou, E., Slastnikova, T. A., Pruszynski, M., Rosenkranz, A. A., Vaidyanathan, G., Sobolev, A. S., et al. (2014). Radiolabeling and in vitro evaluation of (67)Ga-NOTA-modular nanotransporter-a potential Auger electron emitting EGFR-targeted radiotherapeutic. Nucl. Med. Biol. 41, 441-449. doi: 10.1016/j.nucmedbio.2014.03.026

Kovaleva, M., Bussmeyer, I., Rabe, B., Grotzinger, J., Sudarman, E., Eichler, J., et al. (2006). Abrogation of viral interleukin-6 (vIL-6)-induced signaling by intracellular retention and neutralization of vIL-6 with an anti-vIL-6 singlechain antibody selected by phage display. J. Virol. $80,8510-8520$. doi: 10.1128 / JVI.00420-06

Kristensen, M., Birch, D., and Morck, N. H. (2016). Applications and challenges for use of cell-penetrating peptides as delivery vectors for peptide and protein cargos. Int. J. Mol. Sci. 17:E185. doi: 10.3390/ijms17020185

Kumar, S., Aaron, J., and Sokolov, K. (2008). Directional conjugation of antibodies to nanoparticles for synthesis of multiplexed optical contrast agents with both delivery and targeting moieties. Nat. Protoc. 3, 314-320. doi: 10.1038/nprot. 2008.1

Kumar, S., Harrison, N., Richards-Kortum, R., and Sokolov, K. (2007). Plasmonic nanosensors for imaging intracellular biomarkers in live cells. Nano Lett. 7, 1338-1343. doi: 10.1021/nl070365i

Kvam, E., Sierks, M. R., Shoemaker, C. B., and Messer, A. (2010). Physico-chemical determinants of soluble intrabody expression in mammalian cell cytoplasm. Protein Eng. Des. Sel. 23, 489-498. doi: 10.1093/protein/gzq022

Landegren, U. (2016). AFFINOMICS and the prospects for large-scale protein analyses. N. Biotechnol. 33, 491-493. doi: 10.1016/j.nbt.2015.09.006

Larkin, J., Chiarion-Sileni, V., Gonzalez, R., Grob, J. J., Cowey, C. L., Lao, C. D., et al. (2015). Combined nivolumab and ipilimumab or monotherapy in untreated melanoma. N. Engl. J. Med. 373, 23-34. doi: 10.1056/NEJMoa1504030

Lazo, J. S., and Sharlow, E. R. (2016). Drugging undruggable molecular cancer targets. Annu. Rev Pharmacol. Toxicol. 56, 23-40. doi: 10.1146/annurevpharmtox-010715-103440

Lee, S., Kaku, Y., Inoue, S., Nagamune, T., and Kawahara, M. (2016). Growth signalobody selects functional intrabodies in the mammalian cytoplasm. Biotechnol. J. 11, 565-573. doi: 10.1002/biot.201500364

Lenz, H. J. (2006). Anti-EGFR mechanism of action: antitumor effect and underlying cause of adverse events. Oncology 20, 5-13.

Lessman, C. A., Wang, T., Gard, D. L., and Woods, C. W. (1997). Microinjection of anti-alpha-tubulin antibody (DM1A) inhibits progesterone-induced meiotic maturation and deranges the microtubule array in follicle-enclosed oocytes of the frog, Rana Pipiens. Zygote 5, 83-95. doi: 10.1017/S0967199400003592

Li, Y., Liu, Z., Hui, L., Liu, X., Feng, A., Wang, W., et al. (2017). Transbody against virus core protein potently inhibits hepadnavirus replication in vivo: evidence from a duck model of hepatitis B virus. Br. J. Pharmacol. 174, 2261-2272. doi: 10.1111/bph.13811

Liao, X., Rabideau, A. E., and Pentelute, B. L. (2014). Delivery of antibody mimics into mammalian cells via anthrax toxin protective antigen. Chembiochem 15, 2458-2466. doi: 10.1002/cbic.201402290

Lim, K. J., Sung, B. H., Shin, J. R., Lee, Y. W., Kim, D. J., Yang, K. S., et al. (2013). A cancer specific cell-penetrating peptide, BR2, for the efficient delivery of an scFv into cancer cells. PLoS One 8:e66084. doi: 10.1371/journal.pone.0066084 
Lim, S. I., Lukianov, C. I., and Champion, J. A. (2017). Self-assembled protein nanocarrier for intracellular delivery of antibody. J. Control. Release 249, 1-10. doi: 10.1016/j.jconrel.2017.01.007

Lim, Y. T., Cho, M. Y., Lee, J. M., Chung, S. J., and Chung, B. H. (2009). Simultaneous intracellular delivery of targeting antibodies and functional nanoparticles with engineered protein G system. Biomaterials 30, 1197-1204. doi: 10.1016/j.biomaterials.2008.11.007

Liou, J. S., Liu, B. R., Martin, A. L., Huang, Y. W., Chiang, H. J., and Lee, H. J. (2012). Protein transduction in human cells is enhanced by cell-penetrating peptides fused with an endosomolytic HA2 sequence. Peptides 37, 273-284. doi: 10.1016/j.peptides.2012.07.019

Lisi, S., Sisto, M., Soleti, R., Saponaro, C., Scagliusi, P., and D’Amore, M. et al. (2007). Fcgamma receptors mediate internalization of anti-Ro and anti-La autoantibodies from Sjogren's syndrome and apoptosis in human salivary gland cell line A-253. J. Oral Pathol. Med. 36, 511-523. doi: 10.1111/j.1600-0714.2007. 00563.x

Liu, G., Ma, S., Li, S., Cheng, R., Meng, F., Liu, H., et al. (2010). The highly efficient delivery of exogenous proteins into cells mediated by biodegradable chimaeric polymersomes. Biomaterials 31, 7575-7585. doi: 10.1016/j.biomaterials.2010. 06.021

Liu, J., Stevens, J., Matsunami, N., and White, R. L. (2004). Targeted degradation of beta-catenin by chimeric F-box fusion proteins. Biochem. Biophys. Res. Commun. 313, 1023-1029. doi: 10.1016/j.bbrc.2003.12.035

Liu, J. L., Goldman, E. R., Zabetakis, D., Walper, S. A., Turner, K. B., ShriverLake, L. C., et al. (2015). Enhanced production of a single domain antibody with an engineered stabilizing extra disulfide bond. Microb. Cell Fact. 14:158. doi: 10.1186/s12934-015-0340-3

Lohr, F., Lo, D. Y., Zaharoff, D. A., Hu, K., Zhang, X., Li, Y., et al. (2001). Effective tumor therapy with plasmid-encoded cytokines combined with in vivo electroporation. Cancer Res. 61, 3281-3284.

Lukas, J., Bartek, J., and Strauss, M. (1994). Efficient transfer of antibodies into mammalian cells by electroporation. J. Immunol. Methods 170, 255-259. doi: 10.1016/0022-1759(94)90400-6

Lynch, S. M., Zhou, C., and Messer, A. (2008). An scFv intrabody against the nonamyloid component of alpha-synuclein reduces intracellular aggregation and toxicity. J. Mol. Biol. 377, 136-147. doi: 10.1016/j.jmb.2007.11.096

Ma, Y., Gu, Y., Zhang, Q., Han, Y., Yu, S., and Lu, Z. et al. (2013). Targeted degradation of KRAS by an engineered ubiquitin ligase suppresses pancreatic cancer cell growth in vitro and in vivo. Mol. Cancer Ther. 12, 286-294. doi: 10.1158/1535-7163.MCT-12-0650

Ma, Y., Prigent, S. A., Born, T. L., Monell, C. R., Feramisco, J. R., and Bertolaet, B. L. (1999). Microinjection of anti-p21 antibodies induces senescent Hs68 human fibroblasts to synthesize DNA but not to divide. Cancer Res. 59, 5341-5348.

Mallery, D. L., McEwan, W. A., Bidgood, S. R., Towers, G. J., Johnson, C. M., and James, L. C. (2010). Antibodies mediate intracellular immunity through tripartite motif-containing 21 (TRIM21). Proc. Natl. Acad. Sci. U.S.A. 107, 19985-19990. doi: 10.1073/pnas.1014074107

Mann, K., and Kullberg, M. (2016). Trastuzumab-targeted gene delivery to Her2overexpressing breast cancer cells. Cancer Gene Ther. 23, 221-228. doi: 10.1038/ cgt. 2016.21

Marrero, M. B., Schieffer, B., Paxton, W. G., Schieffer, E., and Bernstein, K. E. (1995). Electroporation of pp60c-src antibodies inhibits the angiotensin II activation of phospholipase C-gamma 1 in rat aortic smooth muscle cells. J. Biol. Chem. 270, 15734-15738. doi: 10.1074/jbc.270.26.15734

Marschall, A. L., Zhang, C., Frenzel, A., Schirrmann, T., Hust, M., Perez, F., et al. (2014). Delivery of antibodies to the cytosol: debunking the myths. MAbs 6, 943-956. doi: 10.4161/mabs.29268

Marschall, A. L. J., and Dubel, S. (2016). Antibodies inside of a cell can change its outside: Can intrabodies provide a new therapeutic paradigm? Comput. Struct. Biotechnol. J. 14, 304-308. doi: 10.1016/j.csbj.2016.07.003

Matz, J., Herate, C., Bouchet, J., Dusetti, N., Gayet, O., Baty, D., et al. (2014). Selection of intracellular single-domain antibodies targeting the HIV$1 \mathrm{Vpr}$ protein by cytoplasmic yeast two-hybrid system. PLoS One 9:e113729. doi: 10.1371/journal.pone.0113729

McEwan, W. A., Tam, J. C., Watkinson, R. E., Bidgood, S. R., Mallery, D. L., and James, L. C. (2013). Intracellular antibody-bound pathogens stimulate immune signaling via the Fc receptor TRIM21. Nat. Immunol. 14, 327-336. doi: $10.1038 /$ ni.2548
Mie, M., Takahashi, F., Funabashi, H., Yanagida, Y., Aizawa, M., and Kobatake, E. (2003). Intracellular delivery of antibodies using TAT fusion protein A. Biochem. Biophys. Res Commun. 310, 730-734. doi: 10.1016/j.bbrc.2003.09.071

Miersch, S., and Sidhu, S. S. (2016). Intracellular targeting with engineered proteins. F1000Res. 5:F1000 Faculty Rev-1947.

Milstein, C., and Cuello, A. C. (1983). Hybrid hybridomas and their use in immunohistochemistry. Nature 305, 537-540. doi: 10.1038/305537a0

Mintz, C. S., and Crea, R. (2013). Protein scaffolds. BioProcess Int. 11, 40-48.

Muller, S., Zhao, Y., Brown, T. L., Morgan, A. C., and Kohler, H. (2005). TransMabs: cell-penetrating antibodies, the next generation. Expert Opin. Biol. Ther. 5, 237-241. doi: 10.1517/14712598.5.2.237

Nimmerjahn, F., and Ravetch, J. V. (2008). Fcgamma receptors as regulators of immune responses. Nat. Rev. Immunol. 8, 34-47. doi: 10.1038/nri2206

Noble, P. W., Bernatsky, S., Clarke, A. E., Isenberg, D. A., Ramsey-Goldman, R., and Hansen, J. E. (2016). DNA-damaging autoantibodies and cancer: the lupus butterfly theory. Nat. Rev. Rheumatol. 12, 429-434. doi: 10.1038/nrrheum. 2016.23

Noble, P. W., Chan, G., Young, M. R., Weisbart, R. H., and Hansen, J. E. (2015). Optimizing a lupus autoantibody for targeted cancer therapy. Cancer Res. 75, 2285-2291. doi: 10.1158/0008-5472.CAN-14-2278

Noble, P. W., Young, M. R., Bernatsky, S., Weisbart, R. H., and Hansen, J. E. (2014). A nucleolytic lupus autoantibody is toxic to BRCA2-deficient cancer cells. Sci. Rep. 4:5958. doi: 10.1038/srep05958

Ohara-Imaizumi, M., Nishiwaki, C., Kikuta, T., Kumakura, K., Nakamichi, Y., and Nagamatsu, S. (2004). Site of docking and fusion of insulin secretory granules in live MIN6 beta cells analyzed by TAT-conjugated anti-syntaxin 1 antibody and total internal reflection fluorescence microscopy. J. Biol. Chem. 279, 8403-8408. doi: 10.1074/jbc.M308954200

Ozay, E. I., Gonzalez-Perez, G., Torres, J. A., Vijayaraghavan, J., Lawlor, R., Sherman, H. L., et al. (2016). Intracellular delivery of Anti-pPKCtheta (Thr538) via protein transduction domain mimics for immunomodulation. Mol. Ther. 24, 2118-2130. doi: 10.1038/mt.2016.177

Pan, T., Zhang, Y., Zhou, N., He, X., Chen, C., and Liang, L. et al. (2016). A recombinant chimeric protein specifically induces mutant KRAS degradation and potently inhibits pancreatic tumor growth. Oncotarget 7, 44299-44309. doi: 10.18632/oncotarget.9996

Park, J. S., Cho, M. K., Lee, E. J., Ahn, K. Y., Lee, K. E., Jung, J. H., et al. (2009). A highly sensitive and selective diagnostic assay based on virus nanoparticles. Nat. Nanotechnol. 4, 259-264. doi: 10.1038/nnano.2009.38

Pearson, S., Jia, H., and Kandachi, K. (2004). China approves first gene therapy. Nat. Biotechnol. 22, 3-4. doi: 10.1038/nbt0104-3

Pickart, C. M. (2001). Mechanisms underlying ubiquitination. Annu. Rev. Biochem. 70, 503-533. doi: 10.1146/annurev.biochem.70.1.503

Portnoff, A. D., Stephens, E. A., Varner, J. D., and DeLisa, M. P. (2014). Ubiquibodies, synthetic E3 ubiquitin ligases endowed with unnatural substrate specificity for targeted protein silencing. J. Biol. Chem. 289, 7844-7855. doi: 10.1074/jbc.M113.544825

Postupalenko, V., Sibler, A. P., Desplancq, D., Nomine, Y., Spehner, D., Schultz, P., et al. (2014). Intracellular delivery of functionally active proteins using selfassembling pyridylthiourea-polyethylenimine. J. Control. Release 178, 86-94. doi: 10.1016/j.jconrel.2014.01.017

Poungpair, O., Pootong, A., Maneewatch, S., Srimanote, P., Tongtawe, P., Songserm, T., et al. (2010). A human single chain transbody specific to matrix protein (M1) interferes with the replication of influenza A virus. Bioconjug. Chem. 21, 1134-1141. doi: 10.1021/bc900251u

Qian, L., Fu, J., Yuan, P., Du, S., Huang, W., Li, L., et al. (2018). Intracellular delivery of native proteins facilitated by cell-penetrating poly(disulfide)s. Angew. Chem. Int. Ed. Engl. 57, 1532-1536. doi: 10.1002/anie.201711651

Ratner, M. (2015). IL-17-targeting biologics aim to become standard of care in psoriasis. Nat. Biotechnol. 33, 3-4. doi: 10.1038/nbt0115-3

Rattray, Z., Dubljevic, V., Rattray, N. J. W., Greenwood, D. L., Johnson, C. H., Campbell, J. A., et al. (2018). Re-engineering and evaluation of antiDNA autoantibody 3E10 for therapeutic applications. Biochem. Biophys. Res. Commun. 496, 858-864. doi: 10.1016/j.bbrc.2018.01.139

Reichlin, M. (1998). Cellular dysfunction induced by penetration of autoantibodies into living cells: cellular damage and dysfunction mediated by antibodies to dsDNA and ribosomal P proteins. J. Autoimmun. 11, 557-561. doi: 10.1006/ jaut.1998.0219 
Rhodes, D. A., and Isenberg, D. A. (2017). TRIM21 and the function of antibodies inside cells. Trends Immunol. 38, 916-926. doi: 10.1016/j.it.2017.07.005

Riabowol, K. T., Vosatka, R. J., Ziff, E. B., Lamb, N. J., and Feramisco, J. R. (1988). Microinjection of fos-specific antibodies blocks DNA synthesis in fibroblast cells. Mol. Cell Biol. 8, 1670-1676. doi: 10.1128/MCB.8.4.1670

Richard, J. P., Melikov, K., Brooks, H., Prevot, P., Lebleu, B., and Chernomordik, L. V. (2005). Cellular uptake of unconjugated TAT peptide involves clathrindependent endocytosis and heparan sulfate receptors. J. Biol. Chem. 280, 15300-15306. doi: 10.1074/jbc.M401604200

Richard, J. P., Melikov, K., Vives, E., Ramos, C., Verbeure, B., Gait, M. J., et al. (2003). Cell-penetrating peptides. A reevaluation of the mechanism of cellular uptake. J. Biol. Chem. 278, 585-590. doi: 10.1074/jbc.M209548200

Rinne, J., Albarran, B., Jylhava, J., Ihalainen, T. O., Kankaanpaa, P., Hytonen, V. P., et al. (2007). Internalization of novel non-viral vector TAT-streptavidin into human cells. BMC Biotechnol. 7:1. doi: 10.1186/1472-6750-7-1

Rivadeneyra-Espinoza, L., and Ruiz-Arguelles, A. (2006). Cell-penetrating antinative DNA antibodies trigger apoptosis through both the neglect and programmed pathways. J. Autoimmun. 26, 52-56. doi: 10.1016/j.jaut.2005. 10.008

Roder, R., Helma, J., Preiss, T., Radler, J. O., Leonhardt, H., and Wagner, E. (2017). Intracellular delivery of nanobodies for imaging of target proteins in live cells. Pharm. Res. 34, 161-174. doi: 10.1007/s11095-016-2052-8

Rosenkranz, A. A., Lunin, V. G., Gulak, P. V., Sergienko, O. V., Shumiantseva, M. A., Voronina, O. L., et al. (2003). Recombinant modular transporters for cellspecific nuclear delivery of locally acting drugs enhance photosensitizer activity. FASEB J. 17, 1121-1123. doi: 10.1096/fj.02-0888fje

Rosenkranz, A. A., Slastnikova, T. A., Khramtsov, Y. V., Karyagina, T. S., Georgiev, G. P., and Sobolev, A. S. (2017). Antitumor efficacy of Auger electron emitter (111)In delivered by modular nanotransporter into the nuclei of cells with folate receptor overexpression. Dokl. Biochem. Biophys. 473, 85-87. doi: 10. 1134/S1607672917020016

Rosenkranz, A. A., Vaidyanathan, G., Pozzi, O. R., Lunin, V. G., Zalutsky, M. R., and Sobolev, A. S. (2008). Engineered modular recombinant transporters: application of new platform for targeted radiotherapeutic agents to alphaparticle emitting 211 At. Int. J. Radiat. Oncol. Biol. Phys. 72, 193-200. doi: 10.1016/j.ijrobp.2008.05.055

Roviello, G., Bachelot, T., Hudis, C. A., Curigliano, G., Reynolds, A. R., Petrioli, R., et al. (2017). The role of bevacizumab in solid tumours: a literature based metaanalysis of randomised trials. Eur. J. Cancer 75, 245-258. doi: 10.1016/j.ejca. 2017.01.026

Rui, M., Chen, Y., Zhang, Y., and Ma, D. (2002). Transfer of anti-TFAR19 monoclonal antibody into HeLa cells by in situ electroporation can inhibit the apoptosis. Life Sci. 71, 1771-1778. doi: 10.1016/S0024-3205(02)01943-4

Ruiz-Arguelles, A., Rivadeneyra-Espinoza, L., and Alarcon-Segovia, D. (2003). Antibody penetration into living cells: pathogenic, preventive and immunotherapeutic implications. Curr. Pharm. Des. 9, 1881-1887. doi: 10.2174/ 1381612033454379

Ryan, D. A., Mastrangelo, M. A., Narrow, W. C., Sullivan, M. A., Federoff, H. J., and Bowers, W. J. (2010). Abeta-directed single-chain antibody delivery via a serotype-1 AAV vector improves learning behavior and pathology in Alzheimer's disease mice. Mol. Ther. 18, 1471-1481. doi: 10.1038/mt. 2010.111

Santos, R., Ursu, O., Gaulton, A., Bento, A. P., Donadi, R. S., Bologa, C. G., et al. (2017). A comprehensive map of molecular drug targets. Nat. Rev. Drug Discov. 16, 19-34. doi: 10.1038/nrd.2016.230

Scheer, U., Hinssen, H., Franke, W. W., and Jockusch, B. M. (1984). Microinjection of actin-binding proteins and actin antibodies demonstrates involvement of nuclear actin in transcription of lampbrush chromosomes. Cell 39, 111-122. doi: 10.1016/0092-8674(84)90196-X

Schrader, E. K., Harstad, K. G., and Matouschek, A. (2009). Targeting proteins for degradation. Nat. Chem. Biol. 5, 815-822. doi: 10.1038/nchembio.250

Scott, A. M., Wolchok, J. D., and Old, L. J. (2012). Antibody therapy of cancer. Nat. Rev. Cancer 12, 278-287. doi: 10.1038/nrc3236

Seesuay, W., Jittavisutthikul, S., Sae-Lim, N., Sookrung, N., Sakolvaree, Y., and Chaicumpa, W. (2018). Human transbodies that interfere with the functions of Ebola virus VP35 protein in genome replication and transcription and innate immune antagonism. Emerg. Microbes Infect. 7:41. doi: 10.1038/s41426-018$0031-3$
Senft, D., Qi, J., and Ronai, Z. A. (2018). Ubiquitin ligases in oncogenic transformation and cancer therapy. Nat. Rev. Cancer 18, 69-88. doi: 10.1038/ nrc.2017.105

Sharei, A., Zoldan, J., Adamo, A., Sim, W. Y., Cho, N., Jackson, E., et al. (2013). A vector-free microfluidic platform for intracellular delivery. Proc. Natl. Acad. Sci. U.S.A. 110, 2082-2087. doi: 10.1073/pnas. 1218705110

Shin, I., Edl, J., Biswas, S., Lin, P. C., Mernaugh, R., and Arteaga, C. L. (2005). Proapoptotic activity of cell-permeable anti-Akt single-chain antibodies. Cancer Res. 65, 2815-2824. doi: 10.1158/0008-5472.CAN-04-2898

Shin, S. M., Choi, D. K., Jung, K., Bae, J., Kim, J. S., Park, S. W., et al. (2017). Antibody targeting intracellular oncogenic Ras mutants exerts anti-tumour effects after systemic administration. Nat. Commun. 8:15090. doi: 10.1038/ ncomms 15090

Skrlec, K., Strukelj, B., and Berlec, A. (2015). Non-immunoglobulin scaffolds: a focus on their targets. Trends Biotechnol. 33, 408-418. doi: 10.1016/j.tibtech. 2015.03.012

Slamon, D., Eiermann, W., Robert, N., Pienkowski, T., Martin, M., Press, M., et al. (2011). Adjuvant trastuzumab in HER2-positive breast cancer. N. Engl. J. Med. 365, 1273-1283. doi: 10.1056/NEJMoa0910383

Slastnikova, T. A., Koumarianou, E., Rosenkranz, A. A., Vaidyanathan, G., Lupanova, T. N., Sobolev, A. S., et al. (2012a). Modular nanotransporters: a versatile approach for enhancing nuclear delivery and cytotoxicity of Auger electron-emitting 125I. EJNMMI Res. 2:59. doi: 10.1186/2191-219X-2-59

Slastnikova, T. A., Rosenkranz, A. A., Gulak, P. V., Schiffelers, R. M., Lupanova, T. N., Khramtsov, Y. V., et al. (2012b). Modular nanotransporters: a multipurpose in vivo working platform for targeted drug delivery. Int. J. Nanomedicine 7, 467-482.

Slastnikova, T. A., Rosenkranz, A. A., Khramtsov, Y. V., Karyagina, T. S., Ovechko, S. A., and Sobolev, A. S. (2017a). Development and evaluation of a new modular nanotransporter for drug delivery into nuclei of pathological cells expressing folate receptors. Drug Des Devel. Ther. 11, 1315-1334. doi: 10.2147/DDDT. S127270

Slastnikova, T. A., Rosenkranz, A. A., Lupanova, T. N., Gulak, P. V., Gnuchev, N. V., and Sobolev, A. S. (2012c). Study of efficiency of the modular nanotransporter for targeted delivery of photosensitizers to melanoma cell nuclei in vivo. Dokl. Biochem. Biophys. 446, 235-237. doi: 10.1134/ S1607672912050146

Slastnikova, T. A., Rosenkranz, A. A., Morozova, N. B., Vorontsova, M. S., Petriev, V. M., Lupanova, T. N., et al. (2017b). Preparation, cytotoxicity, and in vivo antitumor efficacy of (111)In-labeled modular nanotransporters. Int. J. Nanomedicine 12, 395-410. doi: 10.2147/IJN.S125359

Smolen, J. S., Landewe, R., Bijlsma, J., Burmester, G., Chatzidionysiou, K., Dougados, M., et al. (2017). EULAR recommendations for the management of rheumatoid arthritis with synthetic and biological disease-modifying antirheumatic drugs: 2016 update. Ann. Rheum. Dis. 76, 960-977. doi: 10.1136/ annrheumdis-2016-210715

Sobolev, A. S. (2009). Modular nanotransporters of anticancer drugs conferring cell specificity and higher efficiency. Biochemistry 74, 1567-1574.

Sobolev, A. S., Aliev, R. A., and Kalmykov, S. N. (2016). Radionuclides emitting short-range particles and modular nanotransporters for their delivery to target cancer cells. Russ. Chem. Rev. 85:1011. doi: 10.1070/RCR4601

Song, Y. C., Sun, G. H., Lee, T. P., Huang, J. C., Yu, C. L., Chen, C. H., et al. (2008). Arginines in the CDR of anti-dsDNA autoantibodies facilitate cell internalization via electrostatic interactions. Eur. J. Immunol. 38, 3178-3190. doi: $10.1002 /$ eji. 200838678

Song, Z., Liu, L., Wang, X., Deng, Y., Nian, Q., Wang, G., et al. (2016). Intracellular delivery of biomineralized monoclonal antibodies to combat viral infection. Chem. Commun. 52, 1879-1882. doi: 10.1039/C5CC09252C

Sousa, F., Castro, P., Fonte, P., Kennedy, P. J., Neves-Petersen, M. T., and Sarmento, B. (2017). Nanoparticles for the delivery of therapeutic antibodies: dogma or promising strategy? Expert. Opin. Drug Deliv. 14, 1163-1176. doi: 10.1080/17425247.2017.1273345

Southwell, A. L., Ko, J., and Patterson, P. H. (2009). Intrabody gene therapy ameliorates motor, cognitive, and neuropathological symptoms in multiple mouse models of Huntington's disease. J. Neurosci. 29, 13589-13602. doi: 10. 1523/JNEUROSCI.4286-09.2009

Srinivasan, A. R., Lakshmikuttyamma, A., and Shoyele, S. A. (2013). Investigation of the stability and cellular uptake of self-associated monoclonal antibody 
(MAb) nanoparticles by non-small lung cancer cells. Mol. Pharm. 10, 3275-3284. doi: 10.1021/mp3005935

Strohl, W. R. (2018). Current progress in innovative engineered antibodies. Protein Cell 9, 86-120. doi: 10.1007/s13238-017-0457-8

Strohl, W. R., and Strohl, L. M. (2012). Therapeutic Antibody Engineering: Current and Future Advances Driving the Strongest Growth Area in The Pharmaceutical Industry. Amsterdam: Elsevier Science doi: 10.1533/9781908818096

Strube, R. W., and Chen, S. Y. (2004). Enhanced intracellular stability of sFv-Fc fusion intrabodies. Methods 34, 179-183. doi: 10.1016/j.ymeth.2004.04.003

Stumpf, M. P., Thorne, T., de, S. E., Stewart, R., An, H. J., Lappe, M., et al. (2008). Estimating the size of the human interactome. Proc. Natl. Acad. Sci. U.S.A. 105, 6959-6964. doi: 10.1073/pnas.0708078105

Su, Y., Ishikawa, S., Kojima, M., and Liu, B. (2003). Eradication of pathogenic betacatenin by Skp1/Cullin/F box ubiquitination machinery. Proc. Natl. Acad. Sci. U.S.A. 100, 12729-12734. doi: 10.1073/pnas.2133261100

Sun, K. H., Tang, S. J., Lin, M. L., Wang, Y. S., Sun, G. H., and Liu, W. T. (2001). Monoclonal antibodies against human ribosomal $\mathrm{P}$ proteins penetrate into living cells and cause apoptosis of Jurkat T cells in culture. Rheumatology 40, 750-756. doi: 10.1093/rheumatology/40.7.750

Sun, K. H., Yu, C. L., Tang, S. J., and Sun, G. H. (2000). Monoclonal antidouble-stranded DNA autoantibody stimulates the expression and release of IL-1beta, IL-6, IL-8, IL-10 and TNF-alpha from normal human mononuclear cells involving in the lupus pathogenesis. Immunology 99, 352-360. doi: 10. 1046/j.1365-2567.2000.00970.x

Svensen, N., Walton, J. G., and Bradley, M. (2012). Peptides for cell-selective drug delivery. Trends Pharmacol. Sci. 33, 186-192. doi: 10.1016/j.tips.2012.02.002

Teimoori, S., Seesuay, W., Jittavisutthikul, S., Chaisri, U., Sookrung, N., Densumite, J., et al. (2016). Human transbodies to VP40 inhibit cellular egress of Ebola virus-like particles. Biochem. Biophys. Res. Commun. 479, 245-252. doi: 10.1016/j.bbrc.2016.09.052

Theisen, D. M., Pongratz, C., Wiegmann, K., Rivero, F., Krut, O., and Kronke, M. (2006). Targeting of HIV-1 Tat traffic and function by transduction-competent single chain antibodies. Vaccine 24, 3127-3136. doi: 10.1016/j.vaccine.2006. 01.055

Tian, X., Nyberg, S., Sharp, S., Madsen, J., Daneshpour, N., Armes, S. P., et al. (2015). LRP-1-mediated intracellular antibody delivery to the central nervous system. Sci. Rep. 5:11990. doi: 10.1038/srep11990

Togtema, M., Pichardo, S., Jackson, R., Lambert, P. F., Curiel, L., and Zehbe, I. (2012). Sonoporation delivery of monoclonal antibodies against human papillomavirus 16 E6 restores p53 expression in transformed cervical keratinocytes. PLoS One 7:e50730. doi: 10.1371/journal.pone.0050730

Tremblay, J. M., Kuo, C. L., Abeijon, C., Sepulveda, J., Oyler, G., Hu, X., et al. (2010). Camelid single domain antibodies (VHHs) as neuronal cell intrabody binding agents and inhibitors of Clostridium botulinum neurotoxin (BoNT) proteases. Toxicon 56, 990-998. doi: 10.1016/j.toxicon.2010.07.003

Ulasov, A. V., Khramtsov, Y. V., Lupanova, T. N., Tsvetkova, A. D., Rosenkranz, A. A., Slastnikova, T. A., et al. (2018). MNT optimization for intracellular delivery of antibody fragments. Dokl. Biochem. Biophys. 479, 62-65. doi: 10 . 1134/S1607672918020023

Van Audenhove, I., Van, I. K., Ruano-Gallego, D., De, C. S., De, M. K., Vanloo, B., et al. (2013). Mapping cytoskeletal protein function in cells by means of nanobodies. Cytoskeleton 70, 604-622. doi: 10.1002/cm.21122

Van Impe, K., Bethuyne, J., Cool, S., Impens, F., Ruano-Gallego, D., De, W. O., et al. (2013). A nanobody targeting the F-actin capping protein CapG restrains breast cancer metastasis. Breast Cancer Res. 15:R116. doi: 10.1186/ bcr3585

Vaughan, T. J., Williams, A. J., Pritchard, K., Osbourn, J. K., Pope, A. R., Earnshaw, J. C., et al. (1996). Human antibodies with sub-nanomolar affinities isolated from a large non-immunized phage display library. Nat. Biotechnol. 14, 309-314. doi: 10.1038/nbt0396-309

Vazquez-Lombardi, R., Phan, T. G., Zimmermann, C., Lowe, D., Jermutus, L., and Christ, D. (2015). Challenges and opportunities for non-antibody scaffold drugs. Drug Discov. Today 20, 1271-1283. doi: 10.1016/j.drudis.2015. 09.004

Verdurmen, W. P., Luginbuhl, M., Honegger, A., and Pluckthun, A. (2015). Efficient cell-specific uptake of binding proteins into the cytoplasm through engineered modular transport systems. J. Control. Release 200, 13-22. doi: 10.1016/j.jconrel.2014.12.019
Verheesen, P., de, K. A., van, K. S., de, B. M., de Haard, H. J., van Ommen, G. J., et al. (2006). Prevention of oculopharyngeal muscular dystrophyassociated aggregation of nuclear polyA-binding protein with a single-domain intracellular antibody. Hum. Mol. Genet. 15, 105-111. doi: 10.1093/hmg/ ddi432

Wang, S., Huttmann, G., Zhang, Z., Vogel, A., Birngruber, R., Tangutoori, S., et al. (2015). Light-Controlled Delivery of Monoclonal Antibodies for Targeted Photoinactivation of Ki-67. Mol. Pharm. 12, 3272-3281. doi: 10.1021/acs. molpharmaceut.5b00260

Ward, E. S., Devanaboyina, S. C., and Ober, R. J. (2015). Targeting FcRn for the modulation of antibody dynamics. Mol. Immunol. 67, 131-141. doi: 10.1016/j. molimm.2015.02.007

Watkinson, R. E., McEwan, W. A., and James, L. C. (2014). Intracellular antibody immunity. J. Clin. Immunol. 34(Suppl 1), S30-S34. doi: 10.1007/s10875-0140017-4

Weinblatt, M. E., Keystone, E. C., Furst, D. E., Moreland, L. W., Weisman, M. H., Birbara, C. A., et al. (2003). Adalimumab, a fully human anti-tumor necrosis factor alpha monoclonal antibody, for the treatment of rheumatoid arthritis in patients taking concomitant methotrexate: the ARMADA trial. Arthritis Rheum. 48, 35-45. doi: 10.1002/art.10697

Weiner, G. J. (2015). Building better monoclonal antibody-based therapeutics. Nat. Rev. Cancer 15, 361-370. doi: 10.1038/nrc3930

Weiner, L. M., Surana, R., and Wang, S. (2010). Monoclonal antibodies: versatile platforms for cancer immunotherapy. Nat. Rev. Immunol. 10, 317-327. doi: $10.1038 /$ nri2744

Weisbart, R. H., Chan, G., Jordaan, G., Noble, P. W., Liu, Y., and Glazer, P. M. et al. (2015). DNA-dependent targeting of cell nuclei by a lupus autoantibody. Sci. Rep. 5:12022 doi: 10.1038/srep12022

Weisbart, R. H., Gera, J. F., Chan, G., Hansen, J. E., Li, E., Cloninger, C., et al. (2012). A cell-penetrating bispecific antibody for therapeutic regulation of intracellular targets. Mol. Cancer Ther. 11, 2169-2173. doi: 10.1158/1535-7163. MCT-12-0476-T

Weisbart, R. H., Hansen, J. E., Chan, G., Wakelin, R., Chang, S. S., and Heinze, E. et al. (2004a). Antibody-mediated transduction of p53 selectively kills cancer cells. Int. J Oncol. 25, 1867-1873. doi: 10.3892/ijo.25.6.1867

Weisbart, R. H., Miller, C. W., Chan, G., Wakelin, R., Ferreri, K., and Koeffler, H. P. (2003). Nuclear delivery of p53 C-terminal peptides into cancer cells using scFv fragments of a monoclonal antibody that penetrates living cells. Cancer Lett. 195, 211-219. doi: 10.1016/S0304-3835(03)00151-4

Weisbart, R. H., Stempniak, M., Harris, S., Zack, D. J., and Ferreri, K. (1998). An autoantibody is modified for use as a delivery system to target the cell nucleus: therapeutic implications. J. Autoimmun. 11, 539-546. doi: 10.1006/jaut.1998. 0212

Weisbart, R. H., Wakelin, R., Chan, G., Miller, C. W., and Koeffler, P. H. (2004b). Construction and expression of a bispecific single-chain antibody that penetrates mutant p53 colon cancer cells and binds p53. Int. J. Oncol. 25, 1113-1118.

Wells, J. A., and McClendon, C. L. (2007). Reaching for high-hanging fruit in drug discovery at protein-protein interfaces. Nature 450, 1001-1009. doi: 10.1038/ nature06526

Wu, Y. C., Wu, T. H., Clemens, D. L., Lee, B. Y., Wen, X., Horwitz, M. A., et al. (2015). Massively parallel delivery of large cargo into mammalian cells with light pulses. Nat. Methods 12, 439-444. doi: 10.1038/nmeth.3357

Wurch, T., Pierre, A., and Depil, S. (2012). Novel protein scaffolds as emerging therapeutic proteins: from discovery to clinical proof-of-concept. Trends Biotechnol. 30, 575-582. doi: 10.1016/j.tibtech.2012.07.006

Yla-Herttuala, S. (2012). Endgame: glybera finally recommended for approval as the first gene therapy drug in the European union. Mol. Ther. 20, 1831-1832. doi: $10.1038 / \mathrm{mt} .2012 .194$

Yoshimi, R., Chang, T. H., Wang, H., Atsumi, T., Morse, H. C. III, and Ozato, K. (2009). Gene disruption study reveals a nonredundant role for TRIM21/Ro52 in NF-kappaB-dependent cytokine expression in fibroblasts. J. Immunol. 182, 7527-7538. doi: 10.4049/jimmunol.0804121

Yun, Y. H., Lee, B. K., and Park, K. (2015). Controlled Drug Delivery: Historical perspective for the next generation. J. Control. Release 219, 2-7. doi: 10.1016/j. jconrel.2015.10.005

Zehner, M., Marschall, A. L., Bos, E., Schloetel, J. G., Kreer, C., and Fehrenschild, D. et al. (2015). The translocon protein Sec61 mediates antigen transport from 
endosomes in the cytosol for cross-presentation to $\mathrm{CD} 8(+) \mathrm{T}$ cells. Immunity 42, 850-863. doi: 10.1016/j.immuni.2015.04.008

Zhang, J. F., Xiong, H. L., Cao, J. L., Wang, S. J., Guo, X. R., Lin, B. Y., et al. (2018). A cell-penetrating whole molecule antibody targeting intracellular $\mathrm{HBx}$ suppresses hepatitis B virus via TRIM21-dependent pathway. Theranostics 8, 549-562. doi: 10.7150/thno.20047

Zhang, W. W., Li, L., Li, D., Liu, J., Li, X., Li, W., et al. (2018). The First Approved Gene Therapy Product for Cancer Ad-p53 (Gendicine): 12 Years in the Clinic. Hum. Gene Ther. 29, 160-179. doi: 10.1089/hum. 2017.218

Zhao, Y., Brown, T. L., Kohler, H., and Muller, S. (2003). MTS-conjugatedantiactive caspase 3 antibodies inhibit actinomycin D-induced apoptosis. Apoptosis 8, 631-637. doi: 10.1023/A:1026139627930

Zhao, Y., Lou, D., Burkett, J., and Kohler, H. (2001). Chemical engineering of cell penetrating antibodies. J. Immunol. Methods 254, 137-145. doi: 10.1016/S00221759(01)00410-0
Zhuang, X., Stahl, S. J., Watts, N. R., DiMattia, M. A., Steven, A. C., and Wingfield, P. T. (2014). A cell-penetrating antibody fragment against HIV-1 Rev has high antiviral activity: characterization of the paratope. J. Biol. Chem. 289, 20222-20233. doi: 10.1074/jbc.M114.581090

Conflict of Interest Statement: The authors declare that the research was conducted in the absence of any commercial or financial relationships that could be construed as a potential conflict of interest.

Copyright (c) 2018 Slastnikova, Ulasov, Rosenkranz and Sobolev. This is an openaccess article distributed under the terms of the Creative Commons Attribution License (CC BY). The use, distribution or reproduction in other forums is permitted, provided the original author(s) and the copyright owner(s) are credited and that the original publication in this journal is cited, in accordance with accepted academic practice. No use, distribution or reproduction is permitted which does not comply with these terms. 